\title{
Bonding and electronic properties of linear diethynyl oligothienoacene-bridged diruthenium complexes and their oxidized forms
}

Article

Accepted Version

Ou, Y.-P., Zhang, J., Zhang, M.-X., Zhang, F., Kuang, D., Hartl, F. and Liu, S. H. (2017) Bonding and electronic properties of linear diethynyl oligothienoacene-bridged diruthenium complexes and their oxidized forms. Inorganic Chemistry, 56 (18). pp. 11074-11086. ISSN 0020-1669 doi:

https://doi.org/10.1021/acs.inorgchem.7b01433 Available at https://centaur.reading.ac.uk/72637/

It is advisable to refer to the publisher's version if you intend to cite from the work. See Guidance on citing.

To link to this article DOI: http://dx.doi.org/10.1021/acs.inorgchem.7b01433

Publisher: American Chemical Society

All outputs in CentAUR are protected by Intellectual Property Rights law, including copyright law. Copyright and IPR is retained by the creators or other copyright holders. Terms and conditions for use of this material are defined in the End User Agreement. 


\section{www.reading.ac.uk/centaur}

\section{CentAUR}

Central Archive at the University of Reading

Reading's research outputs online 
This document is confidential and is proprietary to the American Chemical Society and its authors. Do not copy or disclose without written permission. If you have received this item in error, notify the sender and delete all copies.

\section{Bonding and Electronic Properties of Linear Diethynyl Oligothienoacene-Bridged Diruthenium Complexes and Their Oxidized Forms}

\begin{tabular}{|r|l|}
\hline Journal: & Inorganic Chemistry \\
\hline Manuscript ID & ic-2017-014334.R2 \\
\hline Manuscript Type: & Article \\
\hline Date Submitted by the Author: & $17-$ Aug-2017 \\
\hline Complete List of Authors: & $\begin{array}{l}\text { Ou, Ya-Ping; Hengyang Normal University, College of Chemistry and } \\
\text { Material Science } \\
\text { Zhang, Jing; Central China Normal University, Chemistry } \\
\text { Zhang, Ming-Xing; Central China Normal University, Chemistry } \\
\text { Zhang, Fuxing; Hengyang Normal University, College of Chemistry and } \\
\text { Material Science } \\
\text { Kuang, Daizhi; Hengyang Normal University, College of Chemistry and } \\
\text { Material Science } \\
\text { Hartl, Frantisek; University of Reading, Department of Chemistry } \\
\text { Liu, Sheng-Hua; Central China Normal University, College of Chemistry }\end{array}$ \\
\hline
\end{tabular}

SCHOLARONE ${ }^{\text {Ix }}$

Manuscripts 


\title{
Bonding and Electronic Properties of Linear Diethynyl Oligothienoacene-Bridged Diruthenium Complexes and Their Oxidized Forms
}

Ya-Ping Ou, ${ }^{\ddagger a b}$ Jing Zhang, ${ }^{\ddagger a}$ Ming-Xing Zhang, ${ }^{a}$ Fuxing Zhang, ${ }^{\text {b,c }}$ Daizhi Kuang, ${ }^{\text {b,c }}$ František Hartl, ${ }^{\mathrm{d}}$ and Sheng Hua Liu ${ }^{* \mathrm{a}}$

${ }^{\mathrm{a}}$ Key Laboratory of Pesticide and Chemical Biology, Ministry of Education, College of Chemistry, Central China Normal University, Wuhan 430079, P.R. China

${ }^{\mathrm{b}}$ College of Chemistry and Material Science, Hengyang Normal University, Hengyang, Hunan 421008, P.R. China

${ }^{\mathrm{c}}$ Key Laboratory of Functional Organometallic Materials of Hunan Province College, Hengyang Normal University, Hengyang, Hunan 421008, P.R. China

${ }^{\mathrm{d}}$ Department of Chemistry, University of Reading, Whiteknights, Reading RG6 6AD, U.K.

*Corresponding authors:

E-mail: f.hartl@reading.ac.uk; chshliu@mail.ccnu.edu.cn

$\$$ These authors contributed equally to this work.

\begin{abstract}
A series of five diruthenium diethynyl complexes based on $\alpha, \beta$-fused oligothienoacenes in the core of the bridging ligands (BL), $\left[\left\{\mathrm{Ru}(\mathrm{dppe}) \mathrm{Cp}^{*}\right\}_{2}(\mu-\mathrm{C} \equiv \mathrm{C}-\mathrm{L}-\mathrm{C} \equiv \mathrm{C})\right]($ dppe $=1,2-$ bis(diphenylphosphino)ethane, $\mathrm{Cp} *$ $\left.=\eta^{5}-\mathrm{C}_{5} \mathrm{Me}_{5}\right), \quad \mathrm{L}=$ thieno[3,2-b]thiophene (4), thieno[2,3-b]thiophene (5), 3,4-dimethylthieno[2,3-b]thiophene (6) dithieno[3,2-b:2',3'-d]thiophene (7) and thieno[3,2- $b]$ thieno $\left[2^{\prime}, 3^{\prime}: 4,5\right]$ thieno[2,3- $\left.d\right]$ thiophene (8), have been synthesized and fully characterized electrochemically and spectroscopically. Elongation of the redox non-innocent oligothienoacene bridge core causes a smaller potential difference


between the initial two anodic steps, not seen for free dialkyl oligothienoacenes, and increased positive charge delocalization over the conjugated bridge backbone. The HOMO of the parent complexes resides predominantly on the oligothienoacene core, with strong participation of the ethynyl linkers and slightly smaller contribution from the metallic termini. This bonding character makes the initial one-electron oxidation symmetrical, as revealed by combined voltammetric and spectroscopic (IR, UV-vis-NIR and EPR) methods as well as DFT and TD-DFT calculations of truncated and selected non-truncated models of the studied series. The remarkable gradual appearance of two $\mathrm{C} \equiv \mathrm{C}$ stretching absorptions in the IR spectra of the monocationic diethynyl complexes is ascribed to increasing vibronic coupling of the IR-forbidden $v_{\mathrm{s}}(\mathrm{C} \equiv \mathrm{C})$ mode of the oxidized $-[\mathrm{C} \equiv \mathrm{C} \text {-core- } \mathrm{C} \equiv \mathrm{C}]^{+}-$bridge with a low-lying $\pi-\pi *$ (intra-bridge) / MLCT electronic transition in the NIR-mid-IR spectral region.

\section{Introduction}

Numerous redox-active di- and oligonuclear transition metal complexes exhibit a wide range of important electronic, magnetic and optical properties ${ }^{[1]}$ that can be varied reversibly along readily accessible multiple redox states. Certain physical properties of bimetallic complexes, such as luminescence and non-linear optical (NLO) activity, may display larger variability compared to the monometallic congeners. ${ }^{[2]}$ Specifically in molecular electronics, carefully designed symmetric bimetallic complexes with conjugated bridging ligands and two or more redox centers featuring a variable degree of electronic communication are of central importance to study the mixed-valence (MV) electronic coupling ${ }^{[3]}$ and develop a variety of functional materials. The ability of the molecular bridge to mediate electronic communication has been investigated by a wide range of methods including voltammetric techniques and spectroelectrochemistry (UV-vis-NIR-IR, Raman, EPR, etc.) and theoretical calculations. ${ }^{[4-11]}$

Diruthenium complexes based on a few classical types of redox-active metallic termini supported by ancillary ligands are often explored to test diverse types of 
carbometalated bridging ligands in symmetric MV systems. ${ }^{[12]}$ The electronic coupling between the metal centers strongly depends on the key properties of the bridging ligand, such the degree of conjugation, coplanarity and length. In the earlier literature, researchers have mainly focused on bridging conjugated polyaromatic hydrocarbons (PAHs), ${ }^{[13]}$ such as oligophenylene. ${ }^{[14]}$ Thiophene-based heteroacenes have emerged as excellent building blocks in the synthesis of a variety of opto-electronic materials. These organic semiconductor materials exhibit considerable potential for application as photoswitches ${ }^{[15]}, \operatorname{DSSC}^{[16]}$ and OFETs, ${ }^{[17]}$ owing to their good conjugation. In the field of organometallic chemistry, $\alpha, \beta$-fused oligothienoacene moities have been applied as organic bridging units and introduced to gold- and platinum-containing ethynyl complexes; their physical and luminescent properties were investigated ${ }^{[18]}$. Recently, Lapinte and co-workers ${ }^{[19]}$ have described magnetic communication between two $\left[\mathrm{Fe}(\mathrm{dppe}) \mathrm{Cp}^{*}\right]$ units mediated by the 2,5-diethynylthiophene spacer. Chen and co-workers ${ }^{[20]}$ have also reported thiophene-based bimetallic ruthenium complexes and studied their electron-transfer properties. Subsequently, Liu and co-workers investigated the electronic coupling properties of oligothiophene-bridged binuclear ruthenium complexes (Chart 1) and their charge transfer ability ${ }^{[11 \mathrm{a}]}$. Recent studies ${ }^{[21]}$ document that the charge transport ability across a molecular wire reduces and even drops exponentially with increasing their length. In overall consideration, ${ }^{[22]}$ the fused molecular framework of thienoacenes represents one of the most attractive candidates for low-resistance molecular-scale wires featuring favorable electrical conductance characteristics.

Systematic investigation of thiophene-based heteroacenes with higher conjugation may reveal excellent charge transfer properties. With this in mind, we have synthesized and characterized a series of diethynyl oligothienoacenes as bridging ligands carbometalated to $\mathrm{Ru}(\mathrm{dppe}) \mathrm{Cp}$ * terminal groups, viz. complexes 4-8 (Chart 1) based on thieno[3,2-b]thiophene (4), thieno[2,3-b]thiophene (5), 3,4-dimethylthieno[2,3-b]thiophene (6) dithieno[3,2-b:2',3'-d]thiophene (7) and thieno[3,2- $b]$ thieno $\left[2^{\prime}, 3^{\prime}: 4,5\right]$ thieno[2,3- $\left.d\right]$ thiophene $(8)$ in the bridge core. We aimed (i) to probe with spectro-electrochemistry and quantum chemical calculations how the 
elongation of the oligothienoacene bridge core in complexes 1, 4, 7 and 8 affects their redox and electronic coupling properties, (ii) to evaluate the effect of the positional isomerism and methyl substitution of the dithienoacene bridge core in complexes 4-6 on their electronic properties, and (iii) to compare the new experimental results with those previously reported ${ }^{[11 \mathrm{a}]}$ for closely related complexes $\mathbf{1 - 3}$ with oligothiophenes in the bridge core.

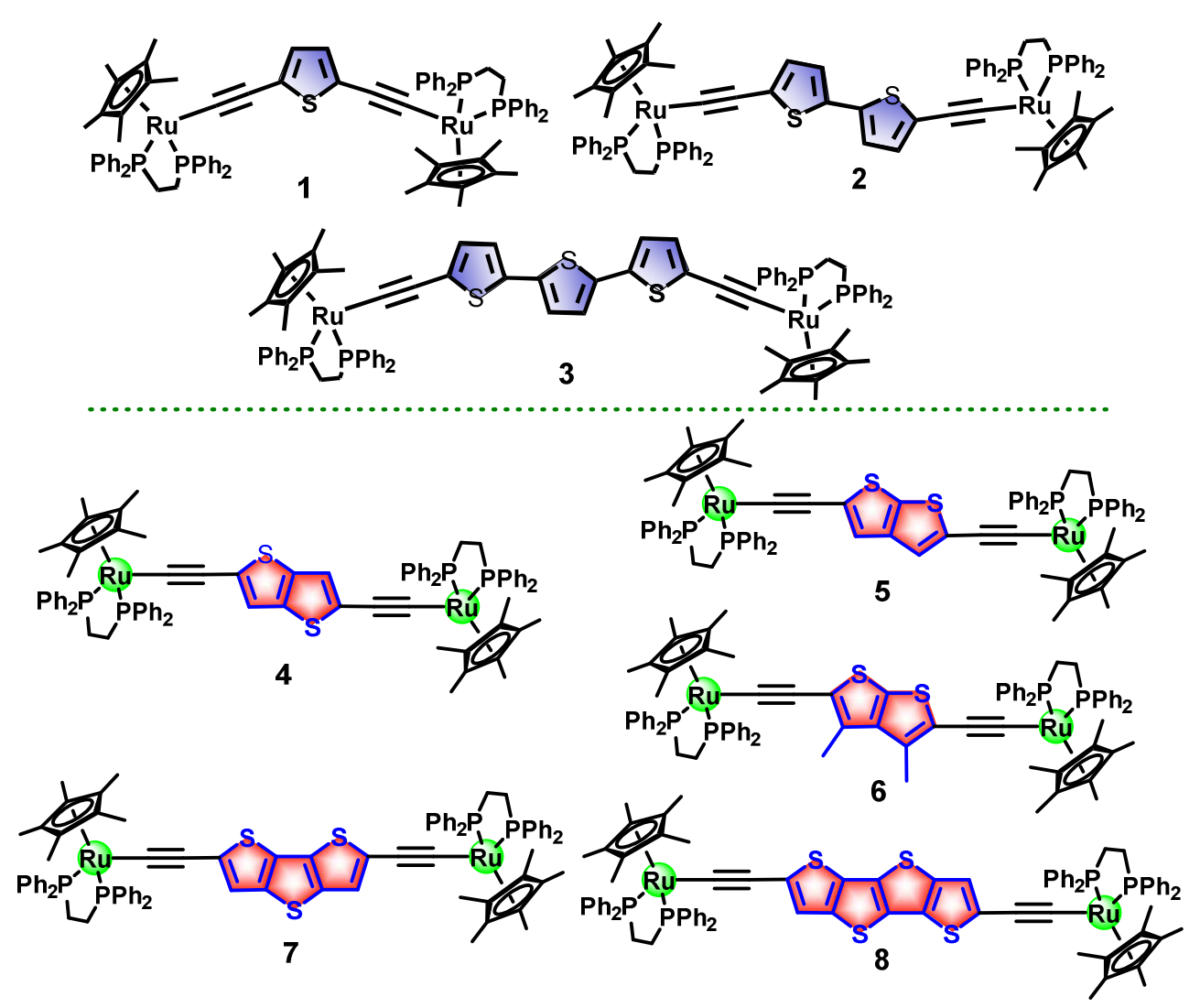

Chart 1. Previously published ${ }^{[11 a]}$ diethynyl oligothiophene-bridged diruthenium complexes 1-3 and the target new series of diethynyl oligothienoacene-bridged diruthenium complexes 4-8. Complex 1 links both groups. Diethynyl dithienoacene isomers 4-6 form a separate sub-group.

\section{Results and Discussion}

\section{Syntheses and Characterization}

The general synthetic route toward diethynyl oligothienoacene-bridged 
diruthenium complexes 4-8 is outlined in Scheme 1. Bridge-core precursors $\mathbf{4 a}^{[23]}$, $\mathbf{5} \mathbf{a}^{[23]}, \mathbf{6} \mathbf{a}^{[24]}, \mathbf{7} \mathbf{a}^{[17,23 b]}, \mathbf{8} \mathbf{a}^{[25]}$ were prepared by the literature methods. Intermediates $\mathbf{4 b - 8 b}$ were obtained in moderate to high yields by palladium(0)/copper(I)-catalysed cross-coupling reactions ${ }^{[26]}$ of trimethylsilylethyne with 2,5-dibromothieno[3,2-b]thiophene (4a), 2,5-dibromothieno[2,3-b]thiophene (5a), 2,5-dibromo-3,4-dimethylthieno[2,3-b]thiophene $(6 a)$, $5,5^{\prime}$-dibromodithieno[3,2-b:2',3'-d] thiophene

(7a) and

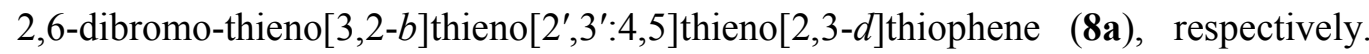
Low solubility of compound $\mathbf{8 a}$ resulted in lower yields (31\%) of complex $\mathbf{8 b}$. Finally, compounds $\mathbf{4 b - 8 b}$ were deprotected by the removal of the TMS group in a methanolic $\mathrm{KF}$ solution, and reacted with [ $\left.\mathrm{RuCl}(\mathrm{dppe}) \mathrm{Cp}^{*}\right]$ for $24 \mathrm{~h}$ at $60{ }^{\circ} \mathrm{C}$. Target complexes 4-8 were collected by filtration and characterized by conventional spectroscopic methods. However, low solubility precluded the collection of sufficiently resolved ${ }^{13} \mathrm{C}$ NMR spectra of complexes 4 and 5. The studied diruthenium complexes exhibit some characteristic ${ }^{1} \mathrm{H}$ NMR signals. For example, complex 7 shows the proton chemical shifts (in ppm) for $\mathrm{C}_{5}\left(\mathrm{CH}_{3}\right)_{5}$ at $\delta$ 1.55, $\mathrm{CH}_{2 / \mathrm{dppe}}$ at $\delta 2.06$ and 2.68, and heptathienoacene- $H$ at $\delta$ 6.42. Tetrathienoacene- $H$ and $\mathrm{CH}_{2 / \text { dppe }}$ signals of complex 4 coincide. Characteristic ${ }^{13} \mathrm{C}$ NMR resonances of $\mathrm{Ru}-\mathrm{C} \equiv \mathrm{C}-$ in $\mathbf{6 - 8}$ are observed at $\delta$ 117. The ${ }^{31} \mathrm{P}$ NMR spectra of complexes 4-8 display only one signal at $\delta 80.00$, reflecting the molecular symmetry. The $v_{\mathrm{as}}(\mathrm{C} \equiv \mathrm{C})$ wavenumber in the IR spectra of the solid diethynyl complexes 1, 4, 7 and 8 (in the Nujol mull) gradually decreases from $2064 \mathrm{~cm}^{-1}$ to $2041 \mathrm{~cm}^{-1}$ as the conjugated bridge core elongates. This trend is in line with the increasing electron-withdrawing power of the oligothienoacene bridge core, reflected in the less negative oxidation potentials (see below). 


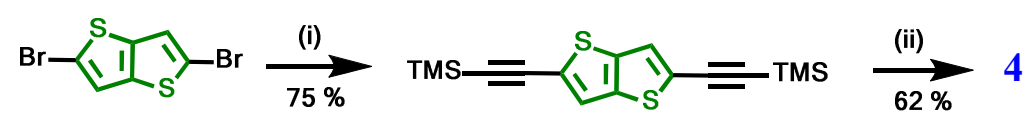

$4 a$

4b

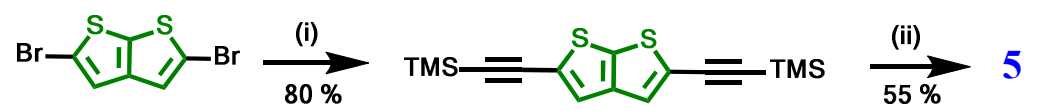

$5 a$

5b

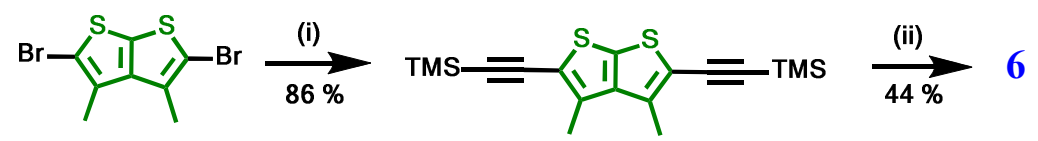

6a

6b
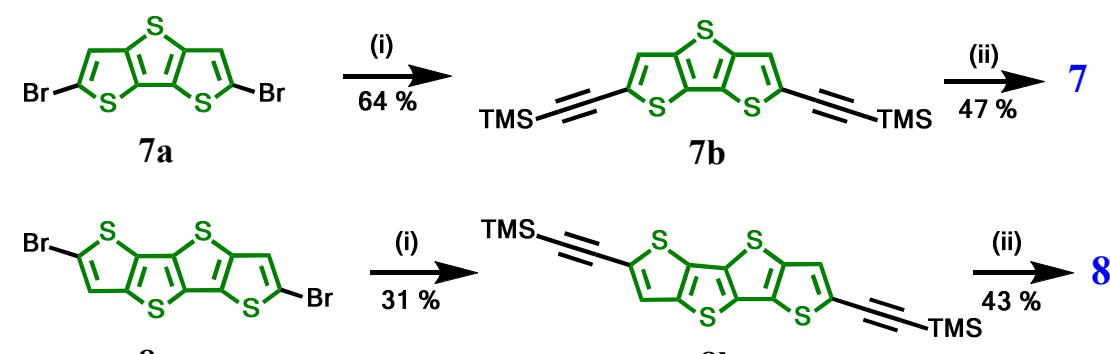

$8 \mathbf{a}$

8b

Scheme 1. Reaction paths to diethynyl oligothienoacene-bridged diruthenium complexes $\mathbf{4 - 8}$, and corresponding reaction yields. Reagents and conditions: (i) TMSA, [Pd( $\left.\left.\mathrm{PPh}_{3}\right)_{4}\right], \mathrm{CuI}$, $\mathrm{THF} /(i-\mathrm{Pr})_{2} \mathrm{NH}$; (ii) $\left[\mathrm{RuCl}(\mathrm{dppe}) \mathrm{Cp}^{*}\right], \mathrm{KF}, \mathrm{CH}_{3} \mathrm{OH} / \mathrm{THF}$. TMSA = trimethylsilylacetylene, dppe = 1,2-bis(diphenylphosphino)ethane, $\mathrm{Cp}^{*}=$ pentamethylcyclopentadiene.

\section{X-ray Structure Determination}

Single crystals of complexes $\mathbf{7}$ and $\mathbf{8}$ suited for X-ray structural analyses were grown by layering the solution in dichloromethane with hexane. The molecular structures of $\mathbf{7}$ and 8, including top and side views, are shown in Figure 1, respectively. Details of the data collection and refinement are presented in Table S1 (Supporting Information). Selected parameters (bond lengths $(\AA)$ and angles (deg)) from the crystal structures of parent $\mathbf{7}$ and $\mathbf{8}$ are collected in Tables 1 and S2 (Supporting Information). Both diruthenium complexes are symmetrical and exhibit a planar rigid structure over the entire bridge (Figure 1). As encountered in other $\mathrm{Ru}(\mathrm{dppe}) \mathrm{Cp} \mathrm{p}^{*}$-based complexes ${ }^{[13]}$, the ethynyl linker and the $\mathrm{Cp}^{*}$ and dppe ligands at the $\mathrm{Ru}$ center form a pseudo-octahedral environment. The $\mathrm{P}(1)-\mathrm{Ru}(1)-\mathrm{P}(2)$ angles in complexes 7 and 8 reach $83.35^{\circ}$ and $83.57^{\circ}$, respectively, falling within the range of 
$83-84^{\circ}$ reported for a number of ruthenium phenylacetylide complexes. ${ }^{[13 b, 27]}$ The bonding parameters of the planar oligothienoacene core, viz.

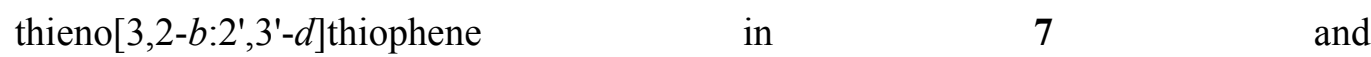
thieno[3,2- $b]$ thieno $\left[2^{\prime}, 3^{\prime}: 4,5\right]$ thieno[2,3- $\left.d\right]$ thiophene in $\mathbf{8}$, do not deviate significantly from those reported for free triisopropylsilyl octathienoacene. ${ }^{[28]}$ The $\mathrm{Ru}(1)-\mathrm{C}(37)-\mathrm{C}(38)$ angles in complexes 7 and 8 are $174.63^{\circ}$ and $168.81^{\circ}$, respectively.

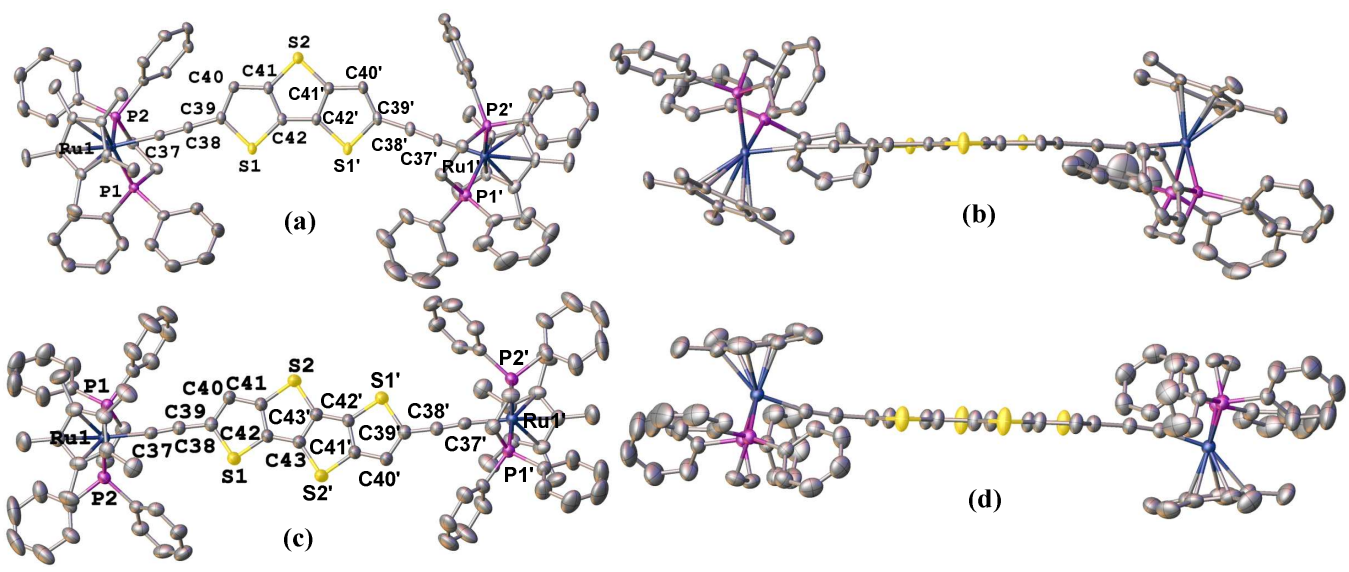

Figure 1. X-ray structures of complexes 7 (a, b) and 8 (c, d) with thermal ellipsoids at the $50 \%$ probability level: $(a, c)$ top view, $(b, d)$ side view. Hydrogen atoms and solvent molecules have been removed for clarity.

Table 1. Selected bond lengths $(\AA)$, angles (deg) and interatomic distance $(\AA)$ from the crystal structure of complex 7 and the DFT-optimized structures of models $[7-\mathbf{H}]^{n+}(n=0,1,2)$ and trans $-7^{+} \cdot$

\begin{tabular}{|c|c|c|c|c|c|c|}
\hline \multirow{2}{*}{$\begin{array}{l}\text { Parameter } \\
\text { Ru1-C37 }\end{array}$} & \multirow{2}{*}{$\begin{array}{c}7 \\
1.986(3)\end{array}$} & \multicolumn{2}{|c|}{$\begin{array}{c}{\text { trans }-7^{+}} \\
(\mathrm{BLYP} 35)^{b}\end{array}$} & \multirow{2}{*}{$\begin{array}{c}\begin{array}{c}{[7-H]} \\
(\mathrm{B} 3 \mathrm{LYP})\end{array} \\
2.011\end{array}$} & \multirow{2}{*}{$\begin{array}{c}\begin{array}{c}\mathbf{[ 7 - H}^{+} \\
(\mathrm{B} 3 \mathrm{LYP})\end{array} \\
1.966\end{array}$} & \multirow{2}{*}{$\begin{array}{c}\begin{array}{c}{ }^{[7-H]^{2+}} \\
(\mathrm{B} 3 \mathrm{LYP})\end{array} \\
1.921\end{array}$} \\
\hline & & 1.913 & 1.910 & & & \\
\hline $\mathrm{Ru} 1-\mathrm{P} 1,2$ & $2.262(7), 2.276(7)$ & $2.281,2.273$ & $2.287,2.277$ & $2.280,2.279$ & $2.301,2.301$ & $2.323,2.322$ \\
\hline C37-C38 & $1.219(4)$ & 1.206 & 1.205 & 1.230 & 1.242 & 1.256 \\
\hline C38-C39 & $1.416(4)$ & 1.336 & 1.338 & 1.401 & 1.373 & 1.351 \\
\hline C39-C40 & $1.372(4)$ & 1.363 & 1.363 & 1.385 & 1.410 & 1.437 \\
\hline $\mathrm{C} 40-\mathrm{C} 41$ & $1.414(4)$ & 1.343 & 1.347 & 1.418 & 1.391 & 1.369 \\
\hline C41-S2 & $1.745(3)$ & 1.697 & 1.697 & 1.757 & 1.756 & 1.757 \\
\hline
\end{tabular}




\begin{tabular}{ccccccc}
\hline C41-C42 & $1.382(4)$ & 1.373 & 1.373 & 1.402 & 1.428 & 1.453 \\
C42-C42' & $1.407(4)$ & 1.349 & 1.349 & 1.418 & 1.392 & 1.371 \\
S1-C42 & $1.722(3)$ & 1.679 & 1.680 & 1.736 & 1.736 & 1.739 \\
S1-C39 & $1.757(3)$ & 1.719 & 1.719 & 1.787 & 1.789 & 1.793 \\
P1-Ru1-P2 & $83.35(3)$ & 83.35 & 83.09 & 93.08 & 92.57 & 91.18 \\
Ru1-C37-C38 & $174.6(2)$ & 174.99 & 173.80 & 178.41 & 178.00 & 177.53 \\
C37-C38-C39 & $179.7(3)$ & 179.53 & 179.50 & 178.90 & 178.07 & 176.71 \\
Ru...Ru' & 15.2 & 14.9 & 14.9 & 15.4 & 15.3 & 15.2 \\
\hline
\end{tabular}

${ }^{a}$ The values are identical for the molecule halves, with the exception of slightly asymmetric trans $-7^{+} .{ }^{b}$ The values for trans $-7^{+}$in the right column correspond to the atom numbering with apostrophes in Figure 1(a).

\section{Electrochemical Studies}

Electronic properties of complexes 4-8 were first studied by electrochemistry revealing differences in their stepwise one-electron oxidation. The separation of two reversible redox waves $\left(\Delta E_{1 / 2}\right)$ is known to be potentially influenced by several factors such as electrostatic interaction, solvation, ion pairing with the electrolyte and structural distortions caused by an electron transfer process ${ }^{[29-32]}$. The anodic responses of the complexes were obtained in $\mathrm{CH}_{2} \mathrm{Cl}_{2} / 10^{-1} \mathrm{M} \mathrm{Bu}_{4} \mathrm{NPF}_{6}$ with cyclic voltammetry $(\mathrm{CV})$ and square-wave voltammetry (SWV); the corresponding data are listed in Table 2. The oxidation potentials of reference complexes 1-3 have been reported in the literature ${ }^{[11 a]}$.

Cyclic and square-wave voltammograms (CVs and SWVs) of complexes 1 and 4-8 are depicted in Figures 2 and 3, and Figures S1-S4 (Supporting Information). All the complexes readily undergo two consecutive fully reversible one-electron oxidations. Figure 3 a reveals that the $E_{1 / 2}(2)$ potential in the oligothienoacene series $\mathbf{1}$, 4, 7 and 8 changes only slightly with the increasing length of the bridge core, while the $E_{1 / 2}(1)$ values increase profoundly, from $-0.387 \mathrm{~V}$ for $\mathbf{1}$ to $-0.180 \mathrm{~V}$ for $\mathbf{8}$. The potential difference $\Delta E_{1 / 2}$ decreases almost linearly from $320 \mathrm{mV}$ to $135 \mathrm{mV}$ with the number (1-4) of the $\alpha, \beta$-fused thiophene rings (Figure 4) and the distance between the terminal ruthenium centers (Figure S5). The increasing delocalization of the unpaired electron/hole over the longer redox non-innocent diethynyl oligothienoacene bridge decreases the further input of energy required to place the other hole into the 
monocationic system. Notably, previously reported diethynyl oligothiophene-bridged complexes $1 \mathbf{- 3}^{[11 \mathrm{a}]}$ exhibit more pronounced changes in $\Delta E_{1 / 2}$ because of the larger amplitude of the chain length variation from single thiophene to bithiophene and linear terthiophene. The comproportionation constants $K_{c}$ for complexes $\mathbf{1 , 4 , 7}$ and $\mathbf{8}$, dwindle along the series from $2.25 \times 10^{5}$ to 191 (Table 2), marking the gradually decreasing thermodynamic stability of the electrochemically generated open-shell monocations.

In contrast to the studied oligothienoacene series with the ruthenium ethynyl termini, the oxidation potentials of free (alkyl)disubstituted oligothienoacenes, $\mathrm{R}-\mathrm{T}_{n}-\mathrm{R}(n=4-8)$, strongly decrease with the chain length and the $\Delta E_{1 / 2}$ values do not decline below $300 \mathrm{mV} .{ }^{[33]}$ This difference in the anodic behavior is one of the characters reflecting the involvement of the conjugated (Ru-)ethynyl units in the stepwise oxidation.

The differences in the anodic potentials are marginal in the series of diethynyl dithienoacene complexes 4, 5 and 6 (Figure $3 b$ and Table 2). The isomerization of the bridge core from thieno[3,2-b]thiophene in $\mathbf{4}$ to thieno[2,3-b]thiophene in $\mathbf{5}$ (with the sulfur atoms located on the same side of the unit) caused a slight positive shift of the anodic potentials and a twice as large $K_{\mathrm{c}}$ value. Even higher stability was observed for $\mathbf{6}^{+}$with two methyl substituents attached to the thieno[2,3-b]thiophene isomer in the bridge core. In contrast to the minor variability of the anodic voltammetric behavior, the structural changes in the dithienoacene series have profound consequences for the NIR-mid-IR electronic and IR vibrational absorption of $\mathbf{4}^{+}-\mathbf{6}^{+}$, as presented in the following section. 


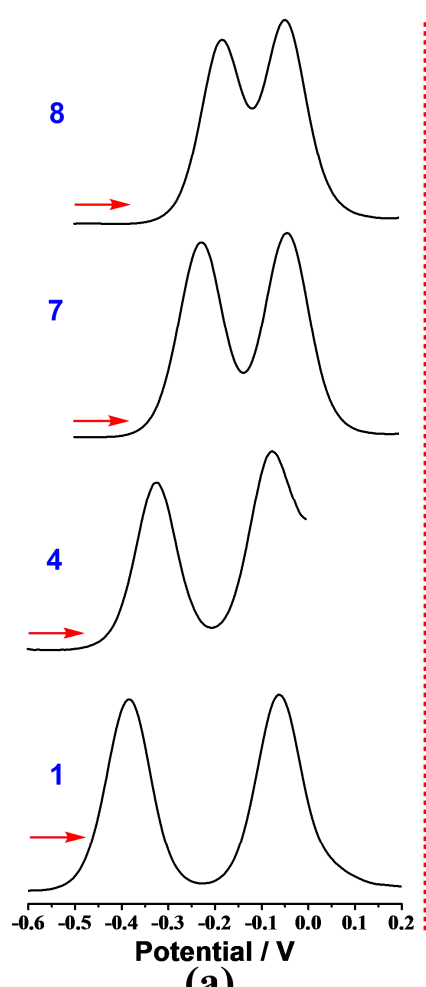

(a)

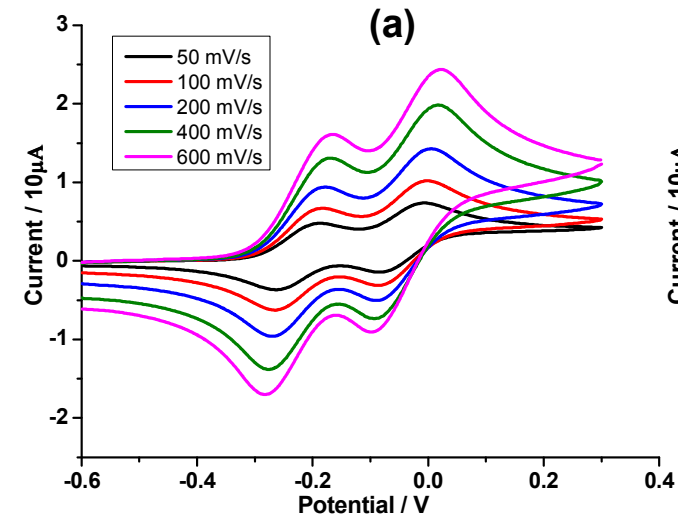

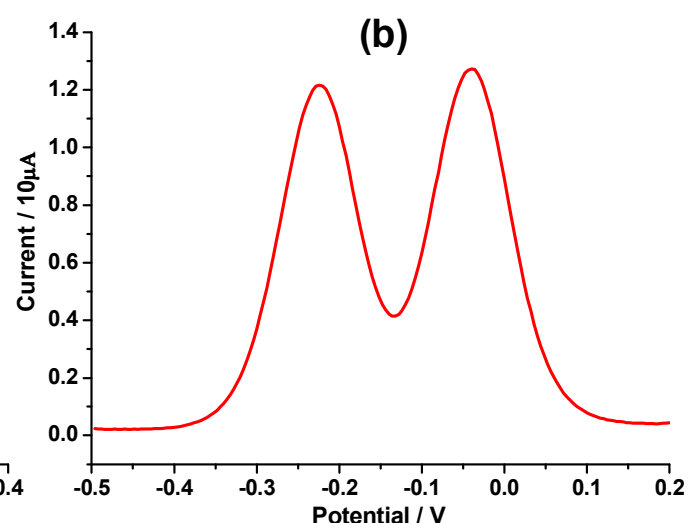

Figure 2. Anodic voltammetric responses of complex 7 in $\mathrm{CH}_{2} \mathrm{Cl}_{2} / \mathrm{Bu}_{4} \mathrm{NPF}_{6}$. (a) Cyclic voltammograms (CVs) at a different scan rate $\left(0.05,0.1,0.2,0.4,0.6 \mathrm{~V} \mathrm{~s}^{-1}\right)$; (b) the square-wave voltammogram (SWV) at $f=10 \mathrm{~Hz}\left(t_{\mathrm{p}}=25 \mathrm{mV}\right)$. The potential scale is referenced vs $\mathrm{Fc} / \mathrm{Fc}^{+}$.

(a)

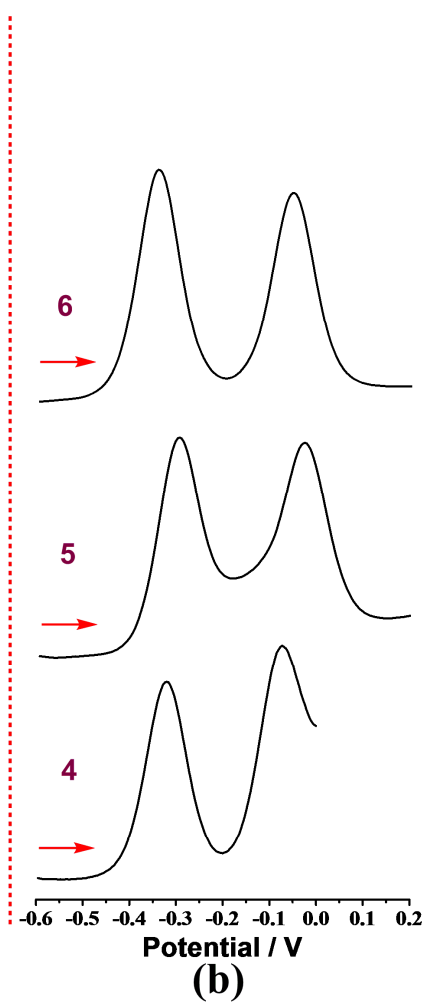

Figure 3. Anodic square-wave voltammograms (SWVs) of (a) the series of oligothienoacene complexes $1,4,7,8$, and (b) the series of dithienoacene complexes $4,5,6$ in $\mathrm{CH}_{2} \mathrm{Cl}_{2} / \mathrm{Bu}_{4} \mathrm{NPF}_{6}, f=$ $10 \mathrm{~Hz}\left(t_{\mathrm{p}}=25 \mathrm{mV}\right)$. The potential scale is referenced $\mathrm{vs} \mathrm{Fc} / \mathrm{Fc}^{+}$. 
Table 2. Electrochemical data determined for complexes 1-8. ${ }^{a}$

\begin{tabular}{ccccc}
\hline Complex & $E_{1 / 2}(1)(\mathrm{V})$ & $E_{1 / 2}(2)(\mathrm{V})$ & $\Delta E_{1 / 2}(\mathrm{mV})^{b}$ & $K_{\mathrm{c}}{ }^{c}$ \\
\hline $\mathbf{1}^{c}$ & -0.387 & -0.067 & 320 & $2.25 \times 10^{5}$ \\
$\mathbf{2}^{c}$ & -0.224 & -0.087 & 137 & 207 \\
$\mathbf{3}^{c, d}$ & -0.052 & -0.132 & 80 & 22.5 \\
$\mathbf{4}$ & -0.320 & -0.072 & 248 & $1.56 \times 10^{4}$ \\
$\mathbf{5}$ & -0.296 & -0.026 & 270 & $3.66 \times 10^{4}$ \\
$\mathbf{6}$ & -0.343 & -0.055 & 288 & $7.61 \times 10^{4}$ \\
$\mathbf{7}$ & -0.224 & -0.040 & 184 & $1.29 \times 10^{3}$ \\
$\mathbf{8}$ & -0.180 & -0.045 & 135 & 191 \\
\hline
\end{tabular}

${ }^{a}$ Electrode potential values vs the $\mathrm{Fc} / \mathrm{Fc}^{+}$standard redox couple recorded at $25{ }^{\circ} \mathrm{C}$ in dry dichloromethane containing $10^{-1} \mathrm{M} \mathrm{Bu}_{4} \mathrm{NPF}_{6}$. Additional anodic waves observed at higher potentials, most likely due to the oligothienoacene bridge core, were not examined further. ${ }^{b} \Delta E_{1 / 2}=E_{1 / 2}(2)-E_{1 / 2}(1) .{ }^{c}$ Ref. $^{11 a}$. The comproportionation constants, $K_{\mathrm{c}}=\exp \left(\Delta E_{1 / 2} / 25.69\right)$ at $298 \mathrm{~K} .{ }^{d}$ Calculated according to ref. ${ }^{[34]}$ for the experimental value $E_{\mathrm{p}}=-0.092 \mathrm{mV}$ (unresolved maxima) and width of $154 \mathrm{mV}$ (the differential-pulse method).

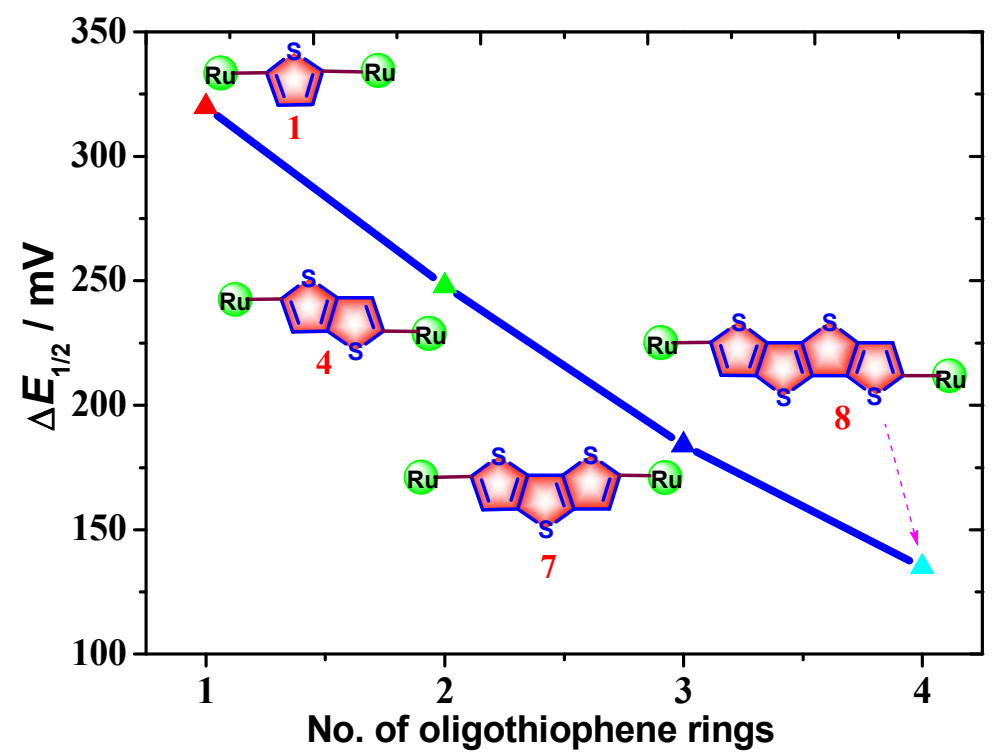

Figure 4. Plot of anodic potential difference $\Delta E_{1 / 2}$ for diruthenium complexes 1, 4, 7 and 8 versus the number of the $\alpha, \beta$-fused thiophene rings in the bridge core.

11 


\section{Chemical Oxidation Monitored by IR and UV-vis-NIR Spectroscopy}

The characteristic infrared $\mathrm{C} \equiv \mathrm{C}$ stretching absorption can conveniently be used to monitor structural changes accompanying the strongly bridge-localized oxidation of the studied series of complexes (Chart 1). The CV and SWV studies have revealed that both the first and second oxidation potentials of complexes 1-8 are lower compared to $E_{1 / 2}$ of the ferrocene standard (Table 2). Ferrocenium hexafluorophosphate, $\mathrm{FcPF}_{6}$, therefore served conveniently as a mild oxidizing agent to selectively generate the corresponding mono- and dications both in the oligothiophene-core series $\mathbf{1 - 3}^{[11 \mathrm{a}]}$ and the new oligothienoacene-core series 4-8.

The $v_{\mathrm{as}}(\mathrm{C} \equiv \mathrm{C})$ vibrational frequencies recorded for complexes $\mathbf{1}^{n+}-\mathbf{8}^{n+}(n=0-2)$ in dichloromethane are presented in Table 3. In the oligothienoacene-core series $\mathbf{1 , 4} \mathbf{4}$ and 8 (Figure 5), the experimental IR spectra in the $v(\mathrm{C} \equiv \mathrm{C})$ region exhibit a single band of low to medium intensities, with absorption maxima shifting gradually to a larger wavenumber for the shorter bridge core, viz. from $2043 \mathrm{~cm}^{-1}$ (for 8) to 2056 $\mathrm{cm}^{-1}$ (for 1). This trend, which is also seen ${ }^{[11 \mathrm{a}]}$ in the diethynyl oligothiophene-bridged series 1-3 (Table 3), indicates less $\pi$-conjugation between the ethynyl linker and the shorter bridge core. As a result, the HOMO energy rises in this direction and the oxidation potential becomes more negative (vide supra). In contrast, the corresponding dications do not display any obvious trend in the main ethynyl stretching wavenumber values, all lying close to $1910 \mathrm{~cm}^{-1}$ (Table 3), in line with the conjugated symmetric $\{\mathrm{M}=\mathrm{C}=\mathrm{C}\}_{2}=\mathrm{C}(\text { core })^{2+}$ backbone. This observation complies with the stagnant electrode potentials for the mono-/dication redox couples (Table 2).

Most interesting observations in the infrared $v(\mathrm{C} \equiv \mathrm{C})$ region have been made for the singly-oxidized cationic species divided into the oligothiophene series 1, 4, 7 and 8, and the dithienoacene series 4-6. Except for $\mathbf{1}^{+}$absorbing at $1961 \mathrm{~cm}^{-1}$, the cations with the elongated oligothienoacene core feature two $v(\mathrm{C} \equiv \mathrm{C})$ absorption bands with increasing separation: $4^{+}\left(\Delta \tilde{v}=26 \mathrm{~cm}^{-1}\right), 7^{+}\left(\Delta \tilde{v}=42 \mathrm{~cm}^{-1}\right)$ and $\mathbf{8}^{+}\left(\Delta \tilde{v}=55 \mathrm{~cm}^{-1}\right)$; the average wavenumber value however remains close to $1961 \mathrm{~cm}^{-1}$ (Table 3). At the same time, the increased band separation is accompanied by rising intensity of the $v(\mathrm{C} \equiv \mathrm{C})$ band at the larger wavenumber. Notably, this trend reaches the maxima in the 
dithienoacene series where $\mathbf{5}^{+}\left(\Delta \tilde{v}=69 \mathrm{~cm}^{-1}\right)$ and $\mathbf{6}^{+}\left(\Delta \tilde{v}=91 \mathrm{~cm}^{-1}\right)$ largely exceed the values obtained for $\mathbf{8}^{+}$. In this case, the remarkable IR spectral changes in the $v(\mathrm{C} \equiv \mathrm{C})$ region cannot be explained the co-existence of different rotamers of the monocations, modelled by DFT calculations, ${ }^{[35-37]}$ as the one-electron oxidation largely resides on the oligothiophene bridge core (see below). Instead, it is important to consider the variable energy of lowest NIR-mid-IR $\pi-\pi^{*}$ (intra-bridge) electronic absorption accompanying the conversion of the neutral parent complexes to the monocations, as highlighted hereinafter.
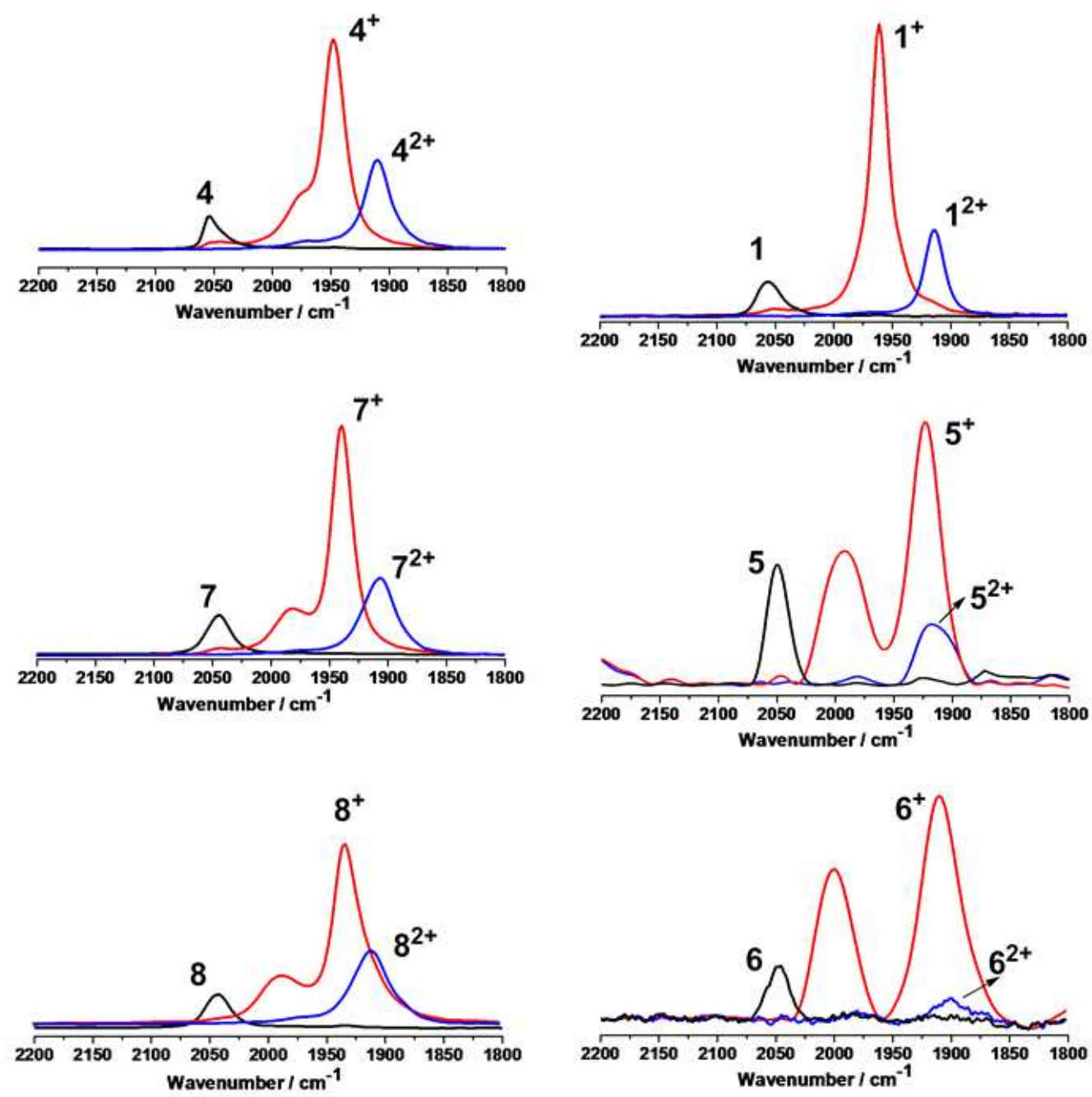

Figure 5. IR spectra in the $v(\mathrm{C} \equiv \mathrm{C})$ region of complexes $\mathbf{1}$ and 4-8 in dichloromethane and their corresponding mono- and dications formed by addition of equivalent amounts of $\mathrm{FcPF}_{6}$. 
Table 3. IR $v(\mathrm{C} \equiv \mathrm{C})$ wavenumbers $\left(\mathrm{cm}^{-1}\right)[$ av. $=$ the average value $]$ recorded for complexes $[\mathbf{1 - 8}]^{n+}$ $(n=0,1,2)$ in dichloromethane. ${ }^{a, b}$

\begin{tabular}{cccc}
\hline Complex & $n=0$ & $n=1$ & $n=2$ \\
\hline $\mathbf{1}^{n+c}$ & $2056(\mathrm{w})$ & $1961(\mathrm{~s})$ [av. 1961] & $1914(\mathrm{~m}-\mathrm{w})$ \\
$\mathbf{2}^{n+c}$ & $2055(\mathrm{w})$ & $1982(\mathrm{sh}), 1933(\mathrm{~s})$ [av. 1958] & $1909(\mathrm{~m}-\mathrm{w})$ \\
$\mathbf{3}^{n+c}$ & $2046(\mathrm{w})$ & $2007(\mathrm{w}), 1920(\mathrm{~m})$ [av. 1964] & $1971(\mathrm{w}), 1917(\mathrm{w})$ \\
$\mathbf{4}^{n+}$ & $2052(\mathrm{w})$ & $1974(\mathrm{sh}), 1948(\mathrm{~s})[\mathrm{av} .1961]$ & $1912(\mathrm{~m}-\mathrm{w})$ \\
$\mathbf{5}^{n+}$ & $2050(\mathrm{~m})$ & $1992(\mathrm{~m}), 1923(\mathrm{~s})$ [av. 1958] & $1916(\mathrm{w})$ \\
$\mathbf{6}^{n+}$ & $2047(\mathrm{w})$ & $2000(\mathrm{~m}-\mathrm{s}), 1909(\mathrm{~s})[\mathrm{av} .1955]$ & $1900(\mathrm{vw})$ \\
$\mathbf{7}^{n+}$ & $2045(\mathrm{w})$ & $1981(\mathrm{w}), 1939(\mathrm{~s})$ [av. 1960] & $1907(\mathrm{~m}-\mathrm{w})$ \\
$\mathbf{8}^{n+}$ & $2043(\mathrm{w})$ & $1988(\mathrm{w}), 1933(\mathrm{~s})$ [av. 1961] & $1911(\mathrm{~m}-\mathrm{w})$ \\
\hline
\end{tabular}

${ }^{a}$ Oxidation of the neutral parent complexes to corresponding mono- and dications was carried out by addition of exact equivalent amounts of ferrocenium hexafluorophosphate. ${ }^{b}$ The low-intensity $v_{\mathrm{s}}(\mathrm{C} \equiv \mathrm{C})$ mode was not detected in the experimental IR spectra of neutral parent complexes and corresponding dications. For 7 and $7^{+}$, both $v_{\mathrm{s}}(\mathrm{C} \equiv \mathrm{C})$ and $v_{\text {as }}(\mathrm{C} \equiv \mathrm{C})$ wavenumbers were obtained by harmonic frequency IR and Raman calculations, see the DFT section. ${ }^{c}$ Ref. ${ }^{[11 \mathrm{a}]}$

Changes in the electronic UV-vis-NIR-IR absorption recorded for complexes 1, 4-8 upon gradual addition of one and two equivalents of the ferrocenium hexafluorophosphate oxidant to their solutions in dichloromethane are depicted in Figure 6 and Figures S6-S8 (Supporting Information). The corresponding electronic absorption data for the neutral parent complexes and their mono- and dications are listed in Table 4. The UV-vis-NIR spectral responses to the two initial oxidation steps within the diruthenium diethynyl oligothienoacene series 1, 4-8 are very similar and will be demonstrated in detail for complex 7 with alternating trithienoacene in the bridge core (Figure 6). Neutral parent 7 exhibits an intense absorption at $445 \mathrm{~nm}$ that corresponds to the HOMO $\rightarrow$ LUMO $\left(\pi-\pi^{*}\right)$ transition characteristic for free oligothienoacenes $^{[33]}$, with participation of the $\pi$-system of the ethynylene linkers. The one-electron oxidation to $7^{+}$generates two intense subgap absorption bands at $683 \mathrm{~nm}$ and $1800 \mathrm{~nm}$ with a shoulder around $1375 \mathrm{~nm}$. This new visible and asymmetric NIR absorption is typical for radical cations of free oligothienoacenes and can be ascribed to $\mathrm{SOMO} \rightarrow \mathrm{LUMO}$ and $\mathrm{HOMO} \rightarrow \operatorname{SOMO}\left(\pi-\pi^{*}\right)$ transitions, respectively. ${ }^{[33]}$ It is 
evident that the oxidation of 7 to $7^{+}$is largely localized on the trithiophene bridge core. The participation of the ( $\mathrm{Ru}-$ )ethynyl linkers, revealed by the IR spectral monitoring and anomalous voltammetric responses (see above), will be discussed in greater detail in the following TD-DFT section. Continued oxidation of $7^{+}$to $7^{2+}$ led to the appearance of a new intense absorption band at $909 \mathrm{~nm}$, which also complies with the dominantly terthiophene-localized anodic steps; in spectra of free oligothiophene dications this band is attributed to a HOMO $\rightarrow$ LUMO $\left(\pi-\pi^{*}\right) \operatorname{transition}^{[33]}$.

All three members of the diethynyl tetrathienoacene redox series, $\mathbf{8}^{n+}(n=0,1,2)$, exhibit the intra-bridge electronic transitions red-shifted compared to $7^{n+}$, while the opposite blue shift is encountered for the two shorter members $4^{n+}$ and $\mathbf{1}^{n+}(n=0,1,2)$. The descendent trends for the elongated oligothienoacene bridge core in each oxidation state are visualized in Figures $6 \mathrm{a}(n=0), 6 \mathrm{~b}(n=1)$ and $6 \mathrm{c}(n=2)$.

Focusing on the remarkable spectral changes observed in the infrared $v(\mathrm{C} \equiv \mathrm{C})$ region of the monocationic $(n=1)$ series (see Figure 5), the analysis of the corresponding NIR electronic absorption provides a strong support for vibronic coupling ${ }^{13 b}$ of the $v(\mathrm{C} \equiv \mathrm{C})$ modes of the oxidized $-[\mathrm{C} \equiv \mathrm{C}-\text { core }-\mathrm{C} \equiv \mathrm{C}]^{+}-$bridge to the low-lying electronic transition. The stronger coupling, taking place on decreasing significantly the excitation energies, activates the $v_{\mathrm{s}}(\mathrm{C} \equiv \mathrm{C})$ mode of the bridge in terms of both gained intensity and wavenumber difference from the asymmetric stretching mode. Thus, for singly oxidized $\mathbf{1}^{+}, \mathbf{4}^{+}, \mathbf{7}^{+}$and $\mathbf{8}^{+}$, the absorption maxima of the lowest NIR absorption bands shift from 7195 to 6370,5555 and $4930 \mathrm{~cm}^{-1}$, respectively, resulting in the pronounced activation of the symmetric stretching mode of the oxidized diethynyl oligothienoacene bridge in the same direction (Figure 5). A strong support for this explanation is obtained from monitoring the oxidation of the diethynyl dithienoacene series, 4-6. Whereas the redox properties in this series are very similar (see Table 2), the energy of the lowest electronic transition further decreases from $6370 \mathrm{~cm}^{-1}$ for $4^{+}$to $4000 \mathrm{~cm}^{-1}$ for $5^{+}$and even $3825 \mathrm{~cm}^{-1}$ for $6^{+}$that is the minimum value in the studied diethynyl oligothienoacene series. Accordingly, the strongest effect on the $v(\mathrm{C} \equiv \mathrm{C})$ modes is observed for $\mathbf{6}^{+}$(Figure 5) showing the largest energy gap $\Delta \tilde{v}=91 \mathrm{~cm}^{-1}$ between the $v(\mathrm{C} \equiv \mathrm{C})$ absorption maxima, and comparable band 
intensities. These characteristics nicely correspond with a very similar situation reported for another singly oxidized $\mathrm{Ru}$ diethynyl complex, viz. $\left[\left\{\mathrm{Ru}(\mathrm{dppe}) \mathrm{Cp}^{*}\right\}_{2}(\mu-\mathrm{C} \equiv \mathrm{C}-\mathrm{L}-\mathrm{C} \equiv \mathrm{C})\right]^{+}, \mathrm{L}=$ benzo[1,2-b;4,3- $\left.b^{\prime}\right]$-dithiophene (bent). ${ }^{[35]}$ In the latter case, the lowest electronic absorption (featuring a mixed ML(bridge)-CT and $\pi-\pi^{*}$ (benzodithiophene) character) lies at $3200 \mathrm{~cm}^{-1}$ and the separation of the two $v(\mathrm{C} \equiv \mathrm{C})$ absorption maxima of comparable intensities reaches $\Delta \tilde{v}=86 \mathrm{~cm}^{-1}$. The substitution with $\mathrm{L}=$ benzo[1,2-b;4,5- $\left.b^{\prime}\right]$ dithiophene (linear) caused a blue shift of the NIR absorption to $4540 \mathrm{~cm}^{-1}$, accompanied by a significant decrease of the $v(\mathrm{C} \equiv \mathrm{C})$ separation to $\Delta \tilde{v}=41 \mathrm{~cm}^{-1}$ and reduced relative intensity of the symmetric stretching mode. The closely related diethynyl oligothiophene series ${ }^{[11 \mathrm{a}]} \mathbf{1}^{+}-\mathbf{3}^{+}$represents another example of the vibronic coupling affecting the $v_{\mathrm{s}}(\mathrm{C} \equiv \mathrm{C})$ vibrations of the singly oxidized bridge.

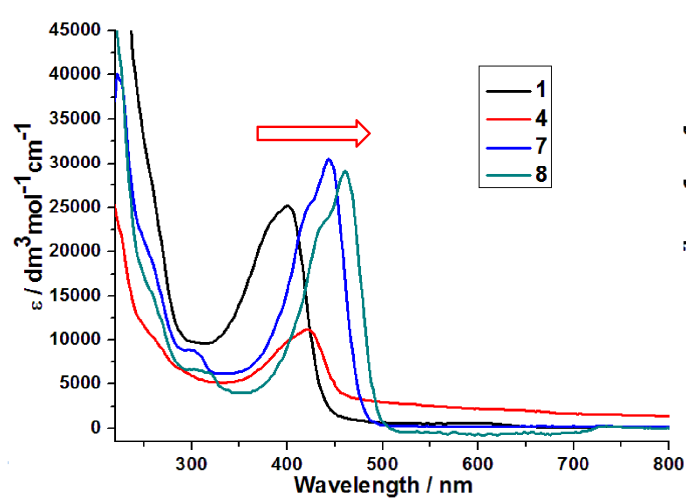

(a)

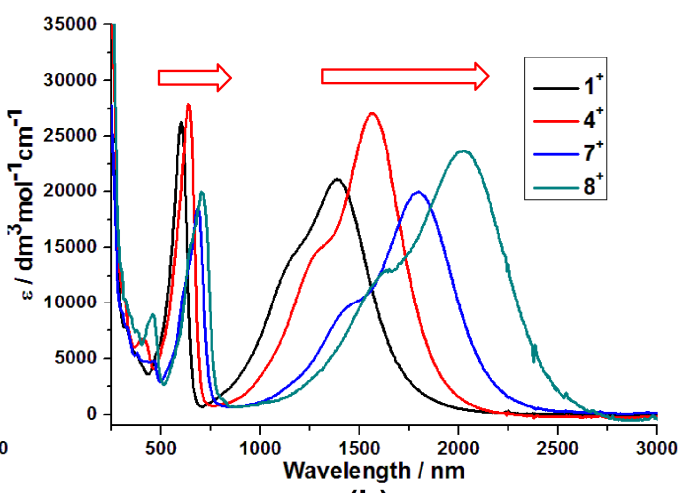

(b)

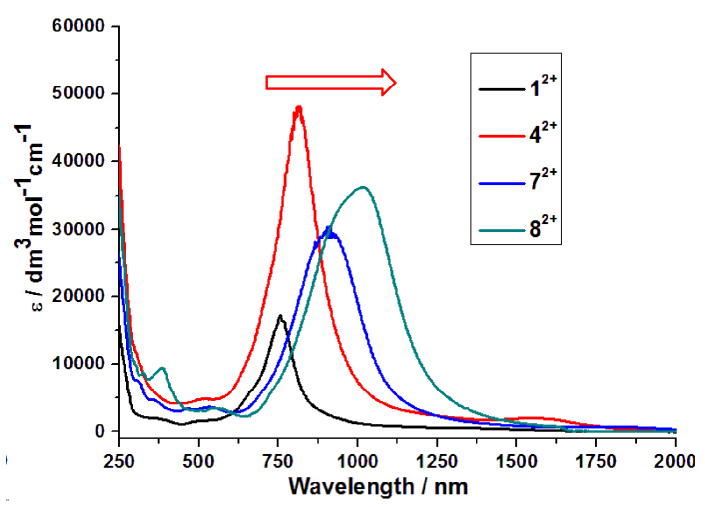

(c)

Figure 6. Red shift of the corresponding (generally intra-bridge) electronic transitions in the UV-vis-NIR absorption spectra recorded for the diruthenium diethynyl oligothienoacene redox 
series $\mathbf{1}^{n+}, \mathbf{4}^{n+}, 7^{n+}$ and $\mathbf{8}^{n+}(n=0,1,2)$, with the increasing length of the oligothienoacene bridge core. (a) $n=0$; (b) $n=1$; (c) $n=2$. Conditions: $\mathrm{CH}_{2} \mathrm{Cl}_{2}, 298 \mathrm{~K}$.

Table 4. Electronic absorption of complexes $\mathbf{1}$ and 4-8 in their mono- and dicationic forms in $\mathrm{CH}_{2} \mathrm{Cl}_{2}$ at $298 \mathrm{~K}^{a}{ }^{a}$

\begin{tabular}{cc}
\hline Complex & $\lambda_{\max }(\mathrm{nm})\left(10^{-4} \varepsilon_{\max }\left(\mathrm{dm}^{3} \mathrm{~mol}^{-1} \mathrm{~cm}^{-1}\right)\right)$ \\
\hline $\mathbf{1}$ & $400(2.51)$ \\
$\mathbf{1}^{+}$ & $600(2.63), 1390(2.11)$ \\
$\mathbf{1}^{2+}$ & $754(1.73)$ \\
$\mathbf{4}$ & $421(1.15)$ \\
$\mathbf{4}^{+}$ & $639(2.81), 1569(2.75)$ \\
$\mathbf{4}^{2+}$ & $812(4.86)$ \\
$\mathbf{5}$ & $336(2.06)$ \\
$\mathbf{5}^{+}$ & $341(1.56), 767(0.52), 2500(0.72)$ \\
$\mathbf{5}^{2+}$ & $346(1.37), 820(0.93), 1237(0.39)$ \\
$\mathbf{6}$ & $429(2.25), 841(0.14)$ \\
$\mathbf{6}^{+}$ & $4411), 799(0.88), 2614(0.68)$ \\
$\mathbf{7}$ & $683(1.89), 1800(2.04)$ \\
$\mathbf{7}^{+}$ & $909(3.05)$ \\
$\mathbf{7}^{2+}$ & $461(2.97)$ \\
$\mathbf{8}$ & $707(2.06), 2028(2.42)$ \\
$\mathbf{8}^{+}$ & $1017(3.67)$ \\
$\mathbf{8}^{2+}$ & $425)$ \\
\hline &
\end{tabular}

${ }^{a}$ Oxidized species $6^{2+}$ was poorly soluble under the given experimental conditions.

\section{DFT and TD-DFT Calculations}

In order to assist the analysis of the molecular and electronic structures in the diethynyl oligothienoacene series $[1]^{\mathrm{n}+},[4]^{\mathrm{n}+},[7]^{\mathrm{n}+}$ and $[8]^{\mathrm{n}+}(n=0,1,2)$, truncated model complexes $[\mathbf{1 - H}]^{\mathrm{n}+},[\mathbf{4}-\mathbf{H}]^{\mathrm{n}+},[\mathbf{7}-\mathbf{H}]^{\mathrm{n}+}$ and $[\mathbf{8}-\mathbf{H}]^{\mathrm{n}+}$ were selected for density functional theory (DFT) calculations at the B3LYP/6-31G* level. The extension "-H" indicates the replacement of the $\mathrm{Cp}^{*}$ and dppe ligands in the parent complexes by $\mathrm{Cp}$ and two $\mathrm{PH}_{3}$ ligands, respectively. Representative non-truncated model complex $7^{+}$ 
has been selected for DFT calculations based on the global hybrid BLYP35 functional and the $6-31 \mathrm{G}^{*}$ basis set, following examples in the literature ${ }^{[13,35-38]}$. Key frontier orbitals of $[\mathbf{4 - H}]^{n+}-[\mathbf{8}-\mathbf{H}]^{n+}(n=0,1,2)$ with electron density distribution are shown in and Figures S9-S13 (Supporting Information). The lists of frontier molecular orbital energies and compositions resulting from Mulliken analysis are provided in Tables S3-S17 (Supporting Information).

DFT (G09-B3LYP)-optimized truncated model structures $[7-\mathbf{H}]^{n+}$ and $[\mathbf{8}-\mathbf{H}]^{n+}$ $(n=0,1,2)$ reveal significant changes in the bond lengths accompanying the sequential one-electron oxidation of the conjugated bridging ligands (see below), i.e., gradual lengthening of the $\mathrm{C} \equiv \mathrm{C}$ and $\mathrm{C}=\mathrm{C}$ bonds and shortening of the $\mathrm{C}-\mathrm{C}$ bonds (Chart 1). The bridge core in the dications obtains a markedly quinoid structure, much like the crystalline dication of free triisopropylsilyl octathienoacene ${ }^{[28]}$; the $\mathrm{Ru}-\mathrm{C} \equiv \mathrm{C}-\mathrm{C}$ (core) moiety converted to delocalized $\{\mathrm{Ru}=\mathrm{C}=\mathrm{C}\}_{2}=\mathrm{C}(\text { core })^{2+}$. More accurate bond lengths and angles in singly oxidized $7^{+}$have been obtained with the G09-BLYP35 DFT method (Table 1). The highest occupied molecular orbitals (HOMOs) of complexes [4-H]-[8-H] are indeed largely delocalized over the diethynyl oligothienoacene bridge, with contributions rising from $76 \%$ to $84 \%$ on elongating the bridge core; the metallic termini become less involved in the same direction.

The calculated spin-density distribution in monocations $[\mathbf{1 - H}]^{+},[\mathbf{4}-\mathbf{H}]^{+},[\mathbf{7 - H}]^{+}$ and $[\mathbf{8}-\mathbf{H}]^{+}$reveals, in line with the parent HOMO characters, that the oxidation is increasingly localized on the elongated diethynyl oligothienoacene bridge, viz. from $72 \%$ in $[\mathbf{1 - H}]^{+}$to $80 \%$ in $[\mathbf{8}-\mathbf{H}]^{+}$. However, the participation of the ethynyl linkers decreases along this series from $36 \%$ in $[\mathbf{1 - H}]^{+}$to $24 \%$ in $[\mathbf{8}-\mathbf{H}]^{+}$, whereas the involvement of the oligothienoacene core rises from $36 \%$ in $[\mathbf{1 - H}]^{+}$to $56 \%$ in $[\mathbf{8}-\mathbf{H}]^{+}$ (Figure 7). These changes have a strong implication for the $v(\mathrm{C} \equiv \mathrm{C})$ wavenumbers in the IR spectra (see below). For the dicationic species, $[\mathbf{1 - H}]^{2+},[\mathbf{4 - H}]^{2+},[\mathbf{7}-\mathbf{H}]^{2+}$ and $[\mathbf{8 - H}]^{2+}$, the HOMO and LUMO are also largely delocalized over ethynyl-core backbone with some participation of the $\mathrm{Ru}$ centers, having a very similar composition as the HOMO-1 and HOMO of the neutral parents (Figures S9-S13, Supporting Information). The LUMO+1 and LUMO are different, except those of 
$[\mathbf{8}-\mathbf{H}]^{2+}$ and $[\mathbf{8}-\mathbf{H}]$, respectively.

The B3LYP DFT calculations yielded single IR $v(\mathrm{C} \equiv \mathrm{C})$ wavenumbers for both neutral $[\mathbf{1 - H}],[\mathbf{4}-\mathbf{H}],[\mathbf{7 - H}]$ and $[\mathbf{8}-\mathbf{H}]$ and the corresponding dications: $[\mathbf{1 - H}]^{n+}-2118$ $\mathrm{cm}^{-1}(n=0)$ and $1980 \mathrm{~cm}^{-1}(n=2) ;[4-\mathbf{H}]^{n+}-2113 \mathrm{~cm}^{-1}(n=0)$ and $1981 \mathrm{~cm}^{-1}(n=2)$; $[\mathbf{7 - H}]^{n+}-2111 \mathrm{~cm}^{-1}(n=0)$ and $1982 \mathrm{~cm}^{-1}(n=2) ;[\mathbf{8}-\mathbf{H}]^{2+}-2110 \mathrm{~cm}^{-1}(n=0)$ and $1986 \mathrm{~cm}^{-1}(n=2)$ (scaled by 0.9614 , see the Computational Details). The large $\Delta \tilde{v}(\mathrm{C} \equiv \mathrm{C})$ values of $143,137,134$ and $129 \mathrm{~cm}^{-1}$ along the series, which are very close to the experimental values of $142,140,138$ and $132 \mathrm{~cm}^{-1}$, respectively (Table 3), reveal significant weakening of the $\mathrm{C} \equiv \mathrm{C}$ bond upon the two-electron oxidation. The smaller $\Delta \tilde{v}(\mathrm{C} \equiv \mathrm{C})$ values reflect the declining involvement of the ethynyl linkers in the oxidation that becomes increasingly localized on the elongated, strongly conjugated oligothienoacene bridge core. The same descending trend applies for the corresponding cationic series $[\mathbf{1 - H}]^{+},[\mathbf{4 - H}]^{+},[\mathbf{7}-\mathbf{H}]^{+}$and $[\mathbf{8 - H}]^{+}$. The calculated $\Delta \tilde{v}(\mathrm{C} \equiv \mathrm{C})$ values of $91,87,85$ and $82 \mathrm{~cm}^{-1}$, respectively, are consistent with the changing spin-density distribution in the model cationic complexes, as shown in Figure 7.

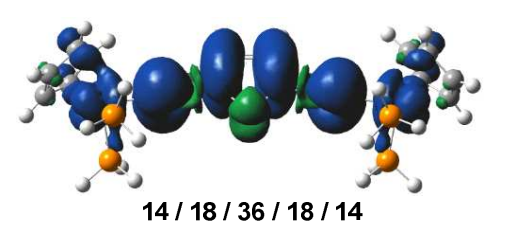

$14 / 18 / 36 / 18 / 14$

$[1-\mathrm{H}]^{+}$

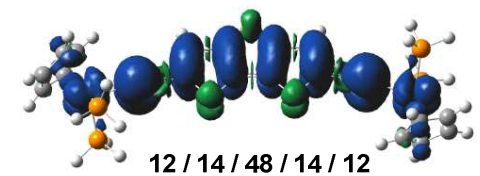

$[7-\mathrm{H}]^{+}$

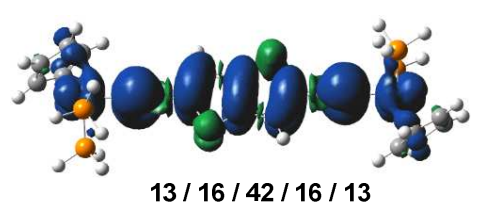

$[4-\mathrm{H}]^{+}$

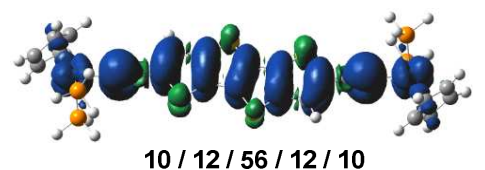

$[8-\mathrm{H}]^{+}$

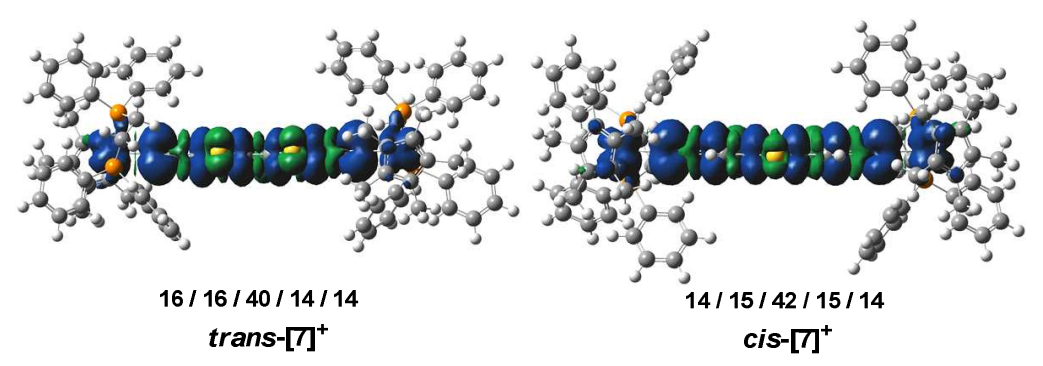

Figure 7. Spin-density distributions in oligothienoacene $\left(T_{n}\right)$-bridged diruthenium monocations

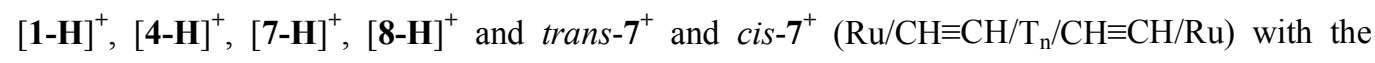


corresponding compositions. Contour values: $\pm 0.0004 \mathrm{e} / \mathrm{bohr}^{3}$.

A number of earlier reported singly oxidized diruthenium diethynyl complexes with a planar aromatic bridge core show multiple $v(\mathrm{C} \equiv \mathrm{C})$ absorption bands assigned to different rotamers with a variable degree of a mixed-valence state. ${ }^{[13,28]}$ Within the studied diethynyl oligothienoacene series, three principal conformations, viz. trans-, cis- and perp-, were modelled for representative non-truncated cation $7^{+}$, having employed the expedient global hybrid functional BLYP35 introduced recently by Kaupp, Low and co-workers. ${ }^{[35-38]}$ The basis set $6-31 \mathrm{G}^{*}$ (Lanl2dz for the Ru atom) was used in combination with the conductor polarizable continuum model (CPCM) in $\mathrm{CH}_{2} \mathrm{Cl}_{2}$. Notably, the DFT method has only afforded potential minima for slightly asymmetrical trans $-7^{+}$(Table 1) and symmetrical cis $-7^{+}$conformations while several optimization programs failed to obtain a stable perpendicular conformation, perp $-7^{+}$. In this regard, $7^{+}$resembles the electronically closely related diethynyl benzodithiophene-bridged diruthenium complexes. ${ }^{36}$ The DFT results obtained for non-truncated isomers trans $-7^{+}$and $c i s-7^{+}$within the harmonic approach show strong $v_{\text {as }}(\mathrm{C} \equiv \mathrm{C})$ absorption at $2231 \mathrm{~cm}^{-1}$; in addition, a very weak $v_{\mathrm{s}}(\mathrm{C} \equiv \mathrm{C})$ band at $2239 \mathrm{~cm}^{-1}$ was obtained for trans $-7^{+}$(scaled by 0.95 , see the Computational Details). In addition, the calculated Raman wavenumbers of the symmetric and asymmetric $\mathrm{C} \equiv \mathrm{C}$ stretching modes for trans $-7^{+}$are identical with the IR results; their absorption intensities are inversed. For comparison, harmonic frequency IR and Raman calculations for parent 7 also yielded $v_{\mathrm{as}}(\mathrm{C} \equiv \mathrm{C})$ and $v_{\mathrm{s}}(\mathrm{C} \equiv \mathrm{C})$ absorptions at $2294 \mathrm{~cm}^{-1}$ and $2298 \mathrm{~cm}^{-1}$, respectively. The $\Delta \tilde{v}(\mathrm{C} \equiv \mathrm{C})$ value calculated for parent 7 and corresponding trans $-7^{+}$is smaller than the experimental value of $106 \mathrm{~cm}^{-1}$ for $v_{\mathrm{as}}(\mathrm{C} \equiv \mathrm{C})$, see Table 3. Both trans $-7^{+}$and $c i s-7^{+}$isomers show almost symmetric distribution of the spin density over the bridge core and ethynyl linkers, viz. trans $-7^{+}: 70 \% ;$ cis $-7^{+}: 72 \%$ (Figure 7), thereby closely resembling truncated $[7-\mathbf{H}]^{+}$. This outcome supports the assumption that the proximity of the electronic absorption in the NIR region is the main factor responsible for the appearance of the two significantly separated IR-active $v(C \equiv C)$ modes of $7^{+}$, as discussed in the preceding spectroscopic section. The origin of the low-energy electronic absorption has been unraveled with TD-DFT (BLYP35) 
calculations carried out on the structurally fully optimized non-truncated models of $7^{+}$ (Figure S14). The major electronic excitations in $\operatorname{trans}-7^{+}$and $c i s-7^{+}$are listed in Table 5. The corresponding isosurface plots of molecular orbitals involved in the major electronic excitations are displayed in Figure S15. Both cationic isomers of $7^{+}$ exhibit an intense absorption band near $7000 \mathrm{~cm}^{-1}$ and two smaller bands between 17000 and $21000 \mathrm{~cm}^{-1}$ (trans $-7^{+}: 7047,17605$, and $20790 \mathrm{~cm}^{-1}$; cis-7 $7^{+}: 7077,17391$, and $20833 \mathrm{~cm}^{-1}$, Table 5), thereby reproducing well the absorption maxima in the NIR and visible region of the experimental electronic absorption spectrum (Figure 6, Table 4). Thus, the strong NIR absorption corresponds to the $\beta$-HOSO $\rightarrow \beta$-LUSO excitation having a dominant $\pi-\pi^{*}$ (diethynyl trithienoacene) character mixed with some ML(bridge)CT. The direct involvement of the ethynyl linkers in the low-energy electronic excitation is not surprising, having a big impact on their vibrational behavior (Figure S15). The visible region features an intense absorption band below $600 \mathrm{~nm}$, largely due to $\alpha$-HOSO $\rightarrow \alpha$-LUSO displaying very similar $\pi-\pi^{*}$ (intra-bridge)/MLCT characteristics (Figure S15). Finally, the fairly weak electronic absorption of the cationic complexes in the blue spectral region, 400-500 $\mathrm{nm}$ (Figure $6 \mathrm{~b}$ ), belongs mainly to $\mathrm{L}\left(\mathrm{Cp}^{*}\right.$, dppe)MCT, also directed to the $\beta$-LUSO.

Table 5. Major electronic excitations of trans- and $c i s-7^{+}$determined by TD-DFT methods.

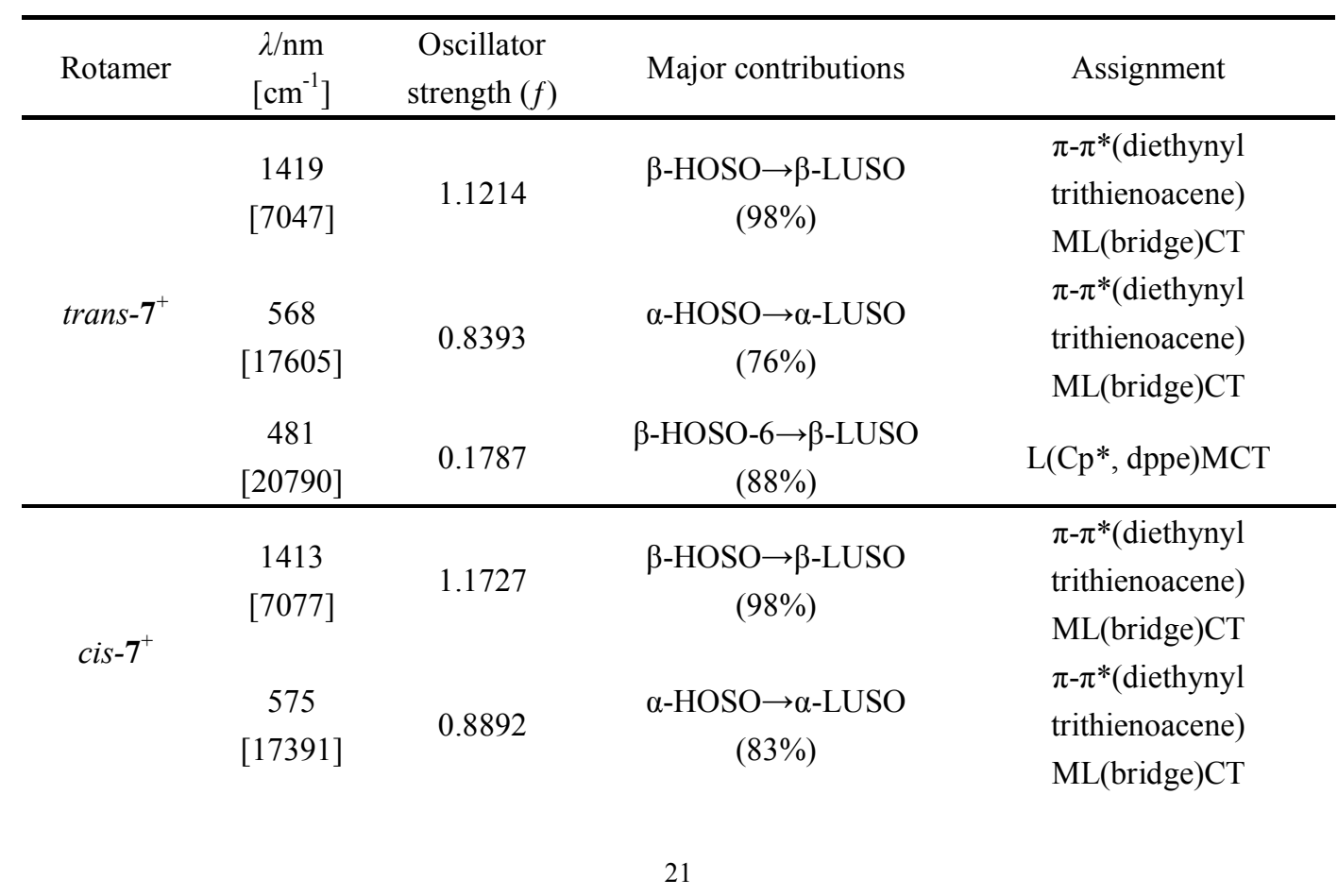




\section{EPR studies}

The contribution of the terminal metal centers and bridging ligands to the one-electron anodic processes was further explored by the EPR spectroscopy for monocations $\mathbf{1}^{+}, \mathbf{4}^{+}, 7^{+}$and $\mathbf{8}^{+}$in $\mathrm{CH}_{2} \mathrm{Cl}_{2}$ at 298 and $150 \mathrm{~K}$. The EPR signals were recorded after having added 1 equiv. of the ferrocenium hexafluorophosphate oxidant (see Figures S16-S19 in Supporting Information). Detailed data are summarized in Table S18. The solutions of the monocations exhibit at $298 \mathrm{~K}$ isotropic singlets with no apparent hyperfine coupling to ${ }^{31} \mathrm{P}$ nuclei of the ancillary dppe ligands. All

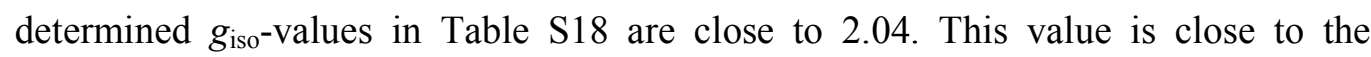
$g$-values for radical cations of free oligothienoacenes ${ }^{[33 b, c]}$ and free electron $\left(g_{\mathrm{e}}=\right.$ 2.0023); the cationic complexes therefore exhibit certain organic radical characters. ${ }^{[39]}$ Importantly, at $150 \mathrm{~K}$, the EPR spectra of the cations displayed broad signals showing only small $g$-tensor anisotropy. The EPR spectra are close to those reported for cationic oligothiophene complexes $\mathbf{1}^{+}-\mathbf{3}^{+} \cdot{ }^{[11 \mathrm{a}]}$ The total $g$-tensor anisotropy $(\Delta g)$ values for complexes $\mathbf{1}^{+}, \mathbf{4}^{+}, 7^{+}$and $\mathbf{8}^{+}$are $0.042,0.040,0.030$ and 0.033 , respectively, falling apparently out of the range of $\Delta g$ values for paramagnetic organometallic complexes with ruthenium(III) centers $(0.3 \sim 0.6)^{[40-43]}$. The small $g_{\text {iso }}$ and $\Delta g$ values in this series of complexes therefore comply with the dominant participation of the diethynyl oligothienoacene bridge in the one-electron oxidation, which is fully consistent with the results of the DFT calculations (vide supra).

\section{Conclusions}

In this work, we describe successful syntheses and full characterization of five redox-responsive diruthenium complexes, 4-8, having thieno[3,2-b]thiophene (4), thieno[2,3-b]thiophene $\quad(\mathbf{5}), \quad 3,4$-dimethylthieno[2,3-b]thiophene 
thieno[3,2- $b]$ thieno $\left[2^{\prime}, 3^{\prime}: 4,5\right]$ thieno[2,3- $\left.d\right]$ thiophene $(\mathbf{8})$ in the core of the diethynyl oligothienoacene bridge. Differently from free oligothienoacenes, the elongation of the bridge core leads to positive potential shifts a reduced potential difference, $\Delta E_{1 / 2}$, between the two anodic steps. This behavior reflects the involvement of ethynyl linkers, and to a small extent even the ruthenium centers, in line with the presented DFT calculations and EPR spectra. In the monocationic series, the spin density is localized symmetrically on the bridge, with an increasing contribution of the elongated oligothienoacene core. This trend for $4^{+}, 7^{+}$and $\mathbf{8}^{+}$cannot explain the appearance of two IR $v(\mathrm{C} \equiv \mathrm{C})$ absorption bands with increasing wavenumber difference along this series and varied intensity ratio. According to the frequency DFT calculations, the IR spectrum of non-truncated model trans $-7^{+}$, electronically very close to the cis-isomer but showing small asymmetry, exhibits one intense $v_{\mathrm{as}}(\mathrm{C} \equiv \mathrm{C})$ band while the $v_{\mathrm{s}}(\mathrm{C} \equiv \mathrm{C})$ absorption is vanishingly low. Other theoretical rotamers on the potential energy landscape with asymmetric localization of the spin density along the molecular backbone have not been obtained. This behavior can be explained by considering a strong vibronic coupling of the $v_{\mathrm{s}}(\mathrm{C} \equiv \mathrm{C})$ mode of the oxidized $-[\mathrm{C} \equiv \mathrm{C}-\text { core }-\mathrm{C} \equiv \mathrm{C}]^{+}-$bridge to a low-lying $\pi-\pi^{*}$ (intra-bridge) / MLCT electronic transition observed in the NIR-IR spectral region. Indeed, the significant red shift of the NIR-IR absorption maxima is accompanied by the conspicuous appearance of the dual $v(\mathrm{C} \equiv \mathrm{C})$ absorption. A strong support for this plausible explanation comes from the diethynyl dithienoacene series $4^{+}-6^{+}$showing otherwise very similar redox properties. The likely general nature of this phenomenon is proposed, based on the literature data for other dinuclear diethynyl complexes with a readily oxidized conjugated bridge core. Our study provides further helpful information for potential applications of redox-responsive conjugated oligothienoacene systems as components of molecular electronic devices. 


\section{Experimental section}

General Materials. All manipulations were carried out at room temperature under a dry nitrogen atmosphere using standard Schlenk techniques, unless otherwise stated. Solvents were pre-dried, distilled, and degassed prior to the use. The main reagents 3-bromothiophene, thieno[2,3-b]thiophene, acetylacetone, $\left[\mathrm{Pd}\left(\mathrm{PPh}_{3}\right)_{4}\right]$ and TMSA were commercially available. The starting materials $\left[\mathrm{RuCl}(\mathrm{dppe}) \mathrm{Cp}^{*}\right]^{[44]}$, 2,5-dibromothieno[3,2-b]thiophene $\quad(\mathbf{4 a})^{[23]}, \quad$ 2,5-dibromothieno[2,3-b]thiophene $(\mathbf{5 a})^{[23]}, \quad$ 2,5-dibromo-3,4-dimethylthieno[2,3-b]thiophene $\quad(6 \mathbf{6 a})^{[24]}$, $5,5^{\prime}$-dibromodithieno[3,2-b:2',3'-d]thiophene $\quad(\mathbf{7 a})^{[17,23 b]} \quad$ and 2,6-dibromo-thieno[3,2- $b]$ thieno $\left[2^{\prime}, 3^{\prime}: 4,5\right]$ thieno[2,3- $\left.d\right]$ thiophene $\quad(\mathbf{8 a})^{[25]} \quad$ were prepared by the literature methods.

\section{Syntheses of bis((trimethylsilyl)ethynyl)thienoacenes ${ }^{[26]}$}

2,5-Bis(trimethylsilylethynyl)thieno[3,2-b]thiophene

$(4 b)$. Trimethylsilylacetylene $(392 \mathrm{mg}, 4.00 \mathrm{mmol}$ ) was added to a stirred solution of 2,5-dibromothieno[3,2-b]thiophene 4a (300 mg, $1.0 \mathrm{mmol})$, CuI (19 mg, $0.10 \mathrm{mmol}$ ), and $\left[\mathrm{Pd}\left(\mathrm{PPh}_{3}\right)_{4}\right](116 \mathrm{mg}, 0.10 \mathrm{mmol})$ in $(i-\mathrm{Pr})_{2} \mathrm{NH}(10 \mathrm{~mL})$ and THF $(10 \mathrm{~mL})$ under an argon atmosphere; the mixture was heated at $60{ }^{\circ} \mathrm{C}$ for $24 \mathrm{~h}$. The solution was then cooled down and filtered through a bed of Celite. The filtrate was evaporated under reduced pressure and purified by silica gel column chromatography (petroleum ether) to give of a light-yellow powder. Yield: $251 \mathrm{mg}, 75 \% .{ }^{1} \mathrm{H} \mathrm{NMR}\left(400 \mathrm{MHz}, \mathrm{CDCl}_{3}\right): \delta$ $0.26\left(\mathrm{~s}, 18 \mathrm{H}, \mathrm{SiCH}_{3}\right), 7.29\left(\mathrm{~s}, 2 \mathrm{H}\right.$, thiophene-H), as reported in ref. ${ }^{[45]}$.

2,5-Bis(trimethylsilylethynyl)thieno[2,3-b]thiophene (5b). This compound was synthesized by the same method as $\mathbf{4 b}$, having used 2,5-dibromothieno[2,3-b]thiophene (5a) (600 mg, $2.00 \mathrm{mmol}$ ), CuI (38 mg, 0.20 $\mathrm{mmol})$, and $\left[\mathrm{Pd}\left(\mathrm{PPh}_{3}\right)_{4}\right](524 \mathrm{mg}, 0.46 \mathrm{mmol}),(i-\mathrm{Pr})_{2} \mathrm{NH}(30 \mathrm{~mL}), \mathrm{THF}(30 \mathrm{~mL})$, trimethylsilylacetylene $(1772 \mathrm{mg}, 18.08 \mathrm{mmol})$. Yield: $535 \mathrm{mg}(80 \%)$ of a light-yellow powder. ${ }^{1} \mathrm{H}$ NMR $\left(400 \mathrm{MHz}, \mathrm{CDCl}_{3}\right): \delta 0.27\left(\mathrm{~s}, 18 \mathrm{H}, \mathrm{SiCH}_{3}\right), 7.16(\mathrm{~s}$, 2H, thiophene-H). EI-MS: $m / z=332.11[\mathrm{M}]^{+}$. Note: the compound was thermally unstable and hence used directly in the next reaction step after the characterization 
and purity check with NMR and MS.

2,5-Bis(trimethylsilylethynyl)-3,4-dimethylthieno[2,3-b]thiophene (6b). This compound was synthesized by the same method as $\mathbf{4 b}$, having used 2,5-dibromo-3,4-dimethylthieno[2,3-b]thiophene (6a) (100 mg, $0.31 \mathrm{mmol})$, CuI (5.85 mg, $0.20 \mathrm{mmol}),\left[\mathrm{Pd}\left(\mathrm{PPh}_{3}\right)_{4}\right](35.5 \mathrm{mg}, 0.41 \mathrm{mmol})$, triethylamine $\left(\mathrm{NEt}_{3}\right)(5$ $\mathrm{mL})$, THF (15 mL), trimethylsilylacetylene (196 mg, $2.00 \mathrm{mmol})$. Yield: $95 \mathrm{mg}(86 \%)$ of a light-yellow powder. ${ }^{1} \mathrm{H}$ NMR $\left(400 \mathrm{MHz}, \mathrm{CDCl}_{3}\right): \delta 0.26\left(\mathrm{~s}, 18 \mathrm{H}, \mathrm{SiCH}_{3}\right), 2.51$ (s, 6H, $\left.\mathrm{CH}_{3}\right) .{ }^{13} \mathrm{C}$ NMR $\left(100 \mathrm{MHz}, \mathrm{CDCl}_{3}\right): \delta 0.0\left(\mathrm{SiMe}_{3}\right), 14.3\left(\mathrm{CH}_{3}\right), 97.4,102.2$, 121.2, 136.5, 137.2, 144.0. Anal. Calcd for $\mathrm{C}_{18} \mathrm{H}_{24} \mathrm{~S}_{2} \mathrm{Si}_{2}:$ C, 59.94; H, 6.71. Found: C, $59.78 ; \mathrm{H}, 6.65$.

5,5'-Bis(trimethylsilylethynyl)dithieno[3,2-b:2',3'-d]thiophene (7b). This compound was synthesized by the same method as $\mathbf{4 b}$, having used 5,5'-dibromodithieno[3,2-b:2',3'-d] thiophene (7a) (800 mg, $2.26 \mathrm{mmol}), \mathrm{CuI}$ (43 mg, $0.23 \mathrm{mmol}),\left[\mathrm{Pd}\left(\mathrm{PPh}_{3}\right)_{4}\right](262 \mathrm{mg}, 0.23 \mathrm{mmol}),(i-\mathrm{Pr})_{2} \mathrm{NH}(30 \mathrm{~mL}), \mathrm{THF}(30 \mathrm{~mL})$, trimethylsilylacetylene (886 mg, $9.04 \mathrm{mmol})$. Yield: $562 \mathrm{mg}(64 \%)$ of a light-yellow powder. ${ }^{1} \mathrm{H}$ NMR $\left(400 \mathrm{MHz}, \mathrm{CDCl}_{3}\right): \delta 0.28\left(\mathrm{~s}, 18 \mathrm{H}, \mathrm{SiCH}_{3}\right), 7.40(\mathrm{~s}, 2 \mathrm{H}$, thiophene-H), as reported in ref. ${ }^{[46]}$.

2,6-Bis(trimethylsilylethynyl)thieno[3,2- $b]$ thieno[ $\left[2^{\prime}, 3^{\prime}: 4,5\right]$ thieno[2,3- $\left.d\right]$ thiophene (8b). This compound was synthesized by the same method as $\mathbf{4 b}$. 2,6-dibromo-thieno[3,2- $b]$ thieno[2',3':4,5] thieno[2,3-d] thiophene (8a) (300 mg, 0.73 $\mathrm{mmol}), \mathrm{CuI}(14 \mathrm{mg}, 0.073 \mathrm{mmol})$, and $\left[\mathrm{Pd}\left(\mathrm{PPh}_{3}\right)_{4}\right](85 \mathrm{mg}, 0.073 \mathrm{mmol}),(i-\mathrm{Pr})_{2} \mathrm{NH}$ $(30 \mathrm{~mL})$, THF $(30 \mathrm{~mL})$, trimethylsilylacetylene $(358 \mathrm{mg}, 3.66 \mathrm{mmol})$. Yield: $100 \mathrm{mg}$ (31\%) of a yellow powder. ${ }^{1} \mathrm{H}$ NMR (400 MHz, $\left.\mathrm{CDCl}_{3}\right): \delta 0.28\left(\mathrm{~s}, 18 \mathrm{H}, \mathrm{SiCH}_{3}\right), 7.42$ (s, 2H, thiophene-H). Anal. Calcd for: $\mathrm{C}_{20} \mathrm{H}_{20} \mathrm{~S}_{4} \mathrm{Si}_{2}: \mathrm{C}, 54.01 ; \mathrm{H}, 4.53$. Found: C, 53.87; H, 4.61. Note: the compound has poor solubility in many deuterated solvents including $\mathrm{CDCl}_{3}$, and the ${ }^{13} \mathrm{C}$ NMR spectrum could not be collected.

\section{General Syntheses of Diruthenium Complexes ${ }^{[11]}$}

Preparation of 4. A solution of $\left[\mathrm{RuCl}(\mathrm{dppe}) \mathrm{Cp}^{*}\right]$ (381 $\mathrm{mg}, 0.57 \mathrm{mmol}$ ), 2,5-bis(trimethylsilylethynyl)thieno[3,2-b]thiophene (4b) (90 $\mathrm{mg}, 0.27 \mathrm{mmol}$ ), and 
$\mathrm{KF}$ (188 mg, $3.24 \mathrm{mmol}$ ) in $20 \mathrm{~mL} \mathrm{CH}_{3} \mathrm{OH}$ and $5 \mathrm{~mL}$ THF was heated to reflux under nitrogen atmosphere for $24 \mathrm{~h}$. The crude product was collected by filtration, washed with methanol and hexane. The solid was dissolved in dichloromethane, precipitated by slow diffusion of hexane, then filtered and dried to give $\mathbf{4}$ as a yellow powder. Yield: $250 \mathrm{mg}, 60 \%$. Note: the compound is poorly soluble in many deuterated solvents including $\mathrm{CDCl}_{3}$, and its ${ }^{13} \mathrm{C}$ NMR spectrum could not be collected. ${ }^{1} \mathrm{H}$ NMR $\left(400 \mathrm{MHz}, \mathrm{CDCl}_{3}\right): \delta 1.57$ (s, 30H, 2C $\left.\mathrm{C}_{5}\left(\mathrm{CH}_{3}\right)_{5}\right), 2.04$ (br, 4H, $\left.\mathrm{CH}_{2 / \mathrm{dppe}}\right), 2.66$ (br, 4H, $\mathrm{CH}_{2 / \text { dppe}}$ ), 7.21-7.37 (m, 32H+2H, $\mathrm{H}_{\text {Ar/dppe }}+\mathrm{H}_{\text {thiophene }}$ ), 7.74 (br, 8H, $\mathrm{H}_{\text {Ar/dppe }}$ ). ${ }^{31} \mathrm{P}$ NMR $\left(160 \mathrm{MHz}, \mathrm{CDCl}_{3}\right): \delta 79.9$ (s, dppe). IR (Nujol/cm $\left.{ }^{-1}\right): v(\mathrm{C} \equiv \mathrm{C}) 2052$ (s). Anal. Calcd for $\mathrm{C}_{82} \mathrm{H}_{80} \mathrm{P}_{4} \mathrm{Ru}_{2} \mathrm{~S}_{2}$ : C, 67.66; H, 5.54. Found: C, 67.71; H, 5.49.

Preparation of $\mathbf{5}$. The synthetic procedure applied to $\mathbf{5}$ mirrored that for $\mathbf{4}$, having used $\quad\left[\mathrm{RuCl}(\mathrm{dppe}) \mathrm{Cp}^{*}\right] \quad(381 \quad \mathrm{mg}, 0.57 \quad \mathrm{mmol})$, 2,5-bis(trimethylsilylethynyl)thieno[2,3-b]thiophene (5b) (90 mg, $0.27 \mathrm{mmol}), \mathrm{KF}$ (188 mg, $3.24 \mathrm{mmol}), \mathrm{CH}_{3} \mathrm{OH}(20 \mathrm{~mL})$, THF $(5 \mathrm{~mL})$. Yield: $221 \mathrm{mg}(55 \%)$ of a yellow solid. Note: the compound is poorly soluble in many deuterated solvents including $\mathrm{CDCl}_{3}$, and its ${ }^{13} \mathrm{C}$ NMR spectrum could not be collected. ${ }^{1} \mathrm{H}$ NMR (400 $\left.\mathrm{MHz}, \mathrm{CDCl}_{3}\right): \delta 1.54\left(\mathrm{~s}, 30 \mathrm{H}, 2 \mathrm{C}_{5}\left(\mathrm{CH}_{3}\right)_{5}\right), 2.05$ (br s, 4H, $\left.\mathrm{CH}_{2 / \mathrm{dppe}}\right), 2.67$ (br s, 4H, $\mathrm{CH}_{2 / \mathrm{dppe}}$ ), 6.27 (s, 2H, $\mathrm{H}_{\text {thiophene }}$ ), 7.21-7.37 (m, 43H, $\mathrm{H}_{\text {Ar/dppe }}$ ), 7.74 (br s, 8H, $\mathrm{H}_{\text {Ar/dppe }}$ ). ${ }^{31} \mathrm{P}$ NMR (160 MHz, $\left.\mathrm{CDCl}_{3}\right): \delta 79.1$ (s, dppe). IR (Nujol/ $\left.\mathrm{cm}^{-1}\right): v(\mathrm{C} \equiv \mathrm{C}) 2050$ (s). Anal. Calcd for $\mathrm{C}_{82} \mathrm{H}_{80} \mathrm{P}_{4} \mathrm{Ru}_{2} \mathrm{~S}_{2}$ : C, 67.66; H, 5.54. Found: C, 67.59; H, 5.56.

Preparation of $\mathbf{6}$. The synthetic procedure applied to $\mathbf{6}$ mirrored that for $\mathbf{4}$, having used [RuCl(dppe)Cp*] (195 mg, 0.29 mmol), 2,5-bis(trimethylsilylethynyl)-3,4dimethylthieno[2,3-b]thiophene (6b) (50 mg, $0.14 \mathrm{mmol})$, KF (97 mg, $1.67 \mathrm{mmol}$ ), $\mathrm{CH}_{3} \mathrm{OH}(20 \mathrm{~mL})$, THF (5 mL). Yield: $97 \mathrm{mg}$ (44\%) of a yellow solid. ${ }^{1} \mathrm{H}$ NMR (400 $\left.\mathrm{MHz}, \mathrm{CDCl}_{3}\right): \delta 1.55\left(\mathrm{~s}, 30 \mathrm{H}, 2 \mathrm{C}_{5}\left(\mathrm{CH}_{3}\right)_{5}\right), 2.01\left(\mathrm{~s}, 6 \mathrm{H}, \mathrm{CH}_{3}\right), 2.11$ (br, 4H, $\mathrm{CH}_{2 / \mathrm{dppe}}$ ), 2.73(br, 4H, $\mathrm{CH}_{2 / \text { dppe }}$ ), 7.17-7.33 (m, 32H, $\mathrm{H}_{\text {Ar/dppe }}$ ), 7.74 (br, 8H, $\mathrm{H}_{\text {Ar/dppe }}$ ). ${ }^{13} \mathrm{C} \mathrm{NMR}$ $\left(100 \mathrm{MHz}, \mathrm{CDCl}_{3}\right): \delta 10.1\left(\mathrm{CH}_{3}\right), 13.6$ (thiophene- $\left.\mathrm{CH}_{3}\right), 29.4(\mathrm{t}, J=23.00 \mathrm{~Hz}$, $\left.\mathrm{CH}_{2 / \mathrm{dppe}}\right), 92.8\left(\mathrm{CH} / \mathrm{C}_{5} \mathrm{Me}_{5}\right), 102.3$ (thiophene- $\left.\mathrm{C} \equiv \mathrm{CH}\right), 117.2(\mathrm{Ru}-\mathrm{C} \equiv \mathrm{CH}), 126.5$, 127.4, 128.8, 128.8, 133.2, 133.7, 136.7, 137.2, 138.7, 139.1. ${ }^{31} \mathrm{P}$ NMR (160 MHz, $\left.\mathrm{CDCl}_{3}\right): \delta(\mathrm{ppm}) 79.9$ (s, dppe). IR (Nujol/ $\left.\mathrm{cm}^{-1}\right): v(\mathrm{C} \equiv \mathrm{C}) 2049$ (s). Anal. Calcd for 
$\mathrm{C}_{84} \mathrm{H}_{86} \mathrm{P}_{4} \mathrm{Ru}_{2} \mathrm{~S}_{2}$ : C, 67.91; H, 5.83. Found: C, 67.87; H, 5.88.

Preparation of $\mathbf{7}$. The synthetic procedure applied to $\mathbf{7}$ mirrored that for $\mathbf{4}$, having used $\quad\left[\mathrm{RuCl}(\mathrm{dppe}) \mathrm{Cp}^{*}\right] \quad(289 \quad \mathrm{mg}, \quad 0.43 \quad \mathrm{mmol})$, 5,5'-bis(trimethylsilylethynyl)dithieno[3,2-b:2',3'-d] thiophene $\quad(7 \mathbf{b}) \quad(80 \mathrm{mg}, \quad 0.21$ mmol), KF (143 mg, $2.47 \mathrm{mmol}), \mathrm{CH}_{3} \mathrm{OH}(20 \mathrm{~mL})$, THF (5 mL). Yield: $155 \mathrm{mg}$ (47\%) of a brown solid. ${ }^{1} \mathrm{H}$ NMR $\left(400 \mathrm{MHz}, \mathrm{CDCl}_{3}\right): \delta 1.55\left(\mathrm{~s}, 30 \mathrm{H}, 2 \mathrm{C}_{5}\left(\mathrm{CH}_{3}\right)_{5}\right), 2.06(\mathrm{br}$, 4H, $\mathrm{CH}_{2 / \mathrm{dppe}}$ ), 2.68 (br, 4H, $\mathrm{CH}_{2 / \mathrm{dppe}}$ ), 6.42 (s, 2H, thiophene), 7.22-7.40 (m, 32H, $\left.\mathrm{H}_{\text {Ar/dppe }}\right), 7.75$ (br, 8H, $\left.\mathrm{H}_{\text {Ar/dppe }}\right) .{ }^{13} \mathrm{C}$ NMR $\left(100 \mathrm{MHz}, \mathrm{CDCl}_{3}\right): \delta 10.0\left(\mathrm{CH}_{3}\right), 29.4(\mathrm{t}, J$ $\left.=22.80 \mathrm{~Hz}, \mathrm{CH}_{2 / \mathrm{dppe}}\right), 92.8\left(\mathrm{CH} / \mathrm{C}_{5} \mathrm{Me}_{5}\right), 102.9$ (thiophene- $\left.\mathrm{C} \equiv \mathrm{CH}\right), 117.1(\mathrm{Ru}-\mathrm{C} \equiv \mathrm{CH})$, $126.5,127.4,129.0,133.2,133.5,136.3,136.8,138.3,138.6,140.2 .{ }^{31} \mathrm{P}$ NMR (160 $\left.\mathrm{MHz}, \mathrm{CDCl}_{3}\right): \delta 79.9$ (s, dppe). IR (Nujol/ $\left.\mathrm{cm}^{-1}\right): v(\mathrm{C} \equiv \mathrm{C}) 2044(\mathrm{w})$. Anal. Calcd for $\mathrm{C}_{84} \mathrm{H}_{80} \mathrm{P}_{4} \mathrm{Ru}_{2} \mathrm{~S}_{3}$ : C, 66.74; H, 5.33. Found: C, 66.69; H, 5.41.

Preparation of 8 . The synthetic procedure applied to 8 mirrored that for 4 , having used $\quad\left[\mathrm{RuCl}(\mathrm{dppe}) \mathrm{Cp}^{*}\right] \quad(158 \quad \mathrm{mg}, 0.24 \quad \mathrm{mmol})$, 2,6-bis(trimethylsilylethynyl)thieno[3,2-b] thieno[2',3':4,5] thieno[2,3- $d]$ thiophene (8b) (50 mg, $0.11 \mathrm{mmol}), \mathrm{KF}$ (78 mg, $1.35 \mathrm{mmol}), \mathrm{CH}_{3} \mathrm{OH}(20 \mathrm{~mL})$, THF (5 mL). Yield: $80 \mathrm{mg}(43 \%)$ of a dark brown solid. ${ }^{1} \mathrm{H}$ NMR $\left(400 \mathrm{MHz}, \mathrm{CDCl}_{3}\right): \delta 1.55(\mathrm{~s}, 30 \mathrm{H}$, 2 $\mathrm{C}_{5}\left(\mathrm{CH}_{3}\right)_{5}$ ), 2.08 (br, 4H, $\mathrm{CH}_{2 / \mathrm{dppe}}$ ), 2.67 (br, 4H, $\mathrm{CH}_{2 / \mathrm{dppe}}$ ), 6.43 (s, 2H, thiophene), 7.31-7.39 (m, 32H, $\left.\mathrm{H}_{\text {Ar/dppe }}\right), 7.75$ (br, 8H, $\left.\mathrm{H}_{\text {Ar/dppe }}\right) .{ }^{13} \mathrm{C}$ NMR (100 MHz, $\left.\mathrm{CDCl}_{3}\right): \delta$ $10.0\left(\mathrm{CH}_{3}\right), 29.6$ (t, $\left.J=22.80 \mathrm{~Hz}, \mathrm{CH}_{2 / \mathrm{dppe}}\right), \quad 93.0 \quad\left(\mathrm{CH} / \mathrm{C}_{5} \mathrm{Me}_{5}\right), \quad 103.0$ (thiophene- $\mathrm{C} \equiv \mathrm{CH}), 117.1(\mathrm{Ru}-\mathrm{C} \equiv \mathrm{CH}), 126.7,127.4,129.0,131.5,132.3,133.2,133.5$, 136.3, 136.8, 137.7, 138.6, 142.0. ${ }^{31} \mathrm{P}$ NMR (160 MHz, $\left.\mathrm{CDCl}_{3}\right): \delta 79.9$ (s, dppe). IR (Nujol/cm $\left.{ }^{-1}\right): v(\mathrm{C} \equiv \mathrm{C}) 2041$ (w). Anal. Calcd for $\mathrm{C}_{86} \mathrm{H}_{80} \mathrm{P}_{4} \mathrm{Ru}_{2} \mathrm{~S}_{4}$ : C, 65.88; H, 5.14. Found: C, 65.95; H, 5.01.

Crystallographic Details. Single crystals of complexes 7 and 8 suitable for X-ray analysis, were grown by slow diffusion of hexane into a solution of dichloromethane. Crystals with approximate dimensions of $0.16 \times 0.12 \times 0.10 \mathrm{~mm}^{3}$ for 7 and $0.12 \times$ $0.10 \times 0.10 \mathrm{~mm}^{3}$ for 8 were mounted on a glass fibre for diffraction experiments. Intensity data were collected on a Nonius Kappa CCD diffractometer with Mo Ka 
radiation $(0.71073 \AA)$ at low temperature $(100 \mathrm{~K})$ for 7 and room temperature (296 K) for $\mathbf{8}$. The structures were solved by a combination of direct methods (SHELXS-97) ${ }^{[47]}$ and Fourier difference techniques and refined by full-matrix least squares $\left(\right.$ SHELXL-97) ${ }^{[48]}$. All non-H atoms were refined anisotropically. The hydrogen atoms were placed in ideal positions and refined as riding atoms. The partial solvent molecules have been omitted. Further crystal data and details of the data collection are summarized in Table S1. Selected bond distances and angles are given in Tables 1 and S2 (Supporting Information), respectively. CCDC number 1504782 \& 1504783 for 7 and 8.

Physical Measurements. ${ }^{1} \mathrm{H},{ }^{13} \mathrm{C}$, and ${ }^{31} \mathrm{P}$ NMR spectra were collected on a Varian Mercury Plus 400 spectrometer (400 MHz). ${ }^{1} \mathrm{H}$ and ${ }^{13} \mathrm{C}$ NMR chemical shifts are given relative to TMS, and ${ }^{31} \mathrm{P}$ NMR chemical shifts to $85 \% \mathrm{H}_{3} \mathrm{PO}_{4}$. Elemental analyses $(\mathrm{C}, \mathrm{H}, \mathrm{N})$ were performed with a Vario ElIII Chnso instrument. UV-vis-NIR spectra were recorded using a Shimadzu UV-3600 spectrophotometer and liquid-sample cells of the $0.2-\mathrm{mm}$ optical path. IR spectra of solid samples dispersed in Nujol between $\mathrm{KBr}$ discs, and solutions in 0.2-mm optical cells were obtained with a Nicolet Avatar spectrometer. Electrochemical measurements were conducted with a CHI 660C potentiostat. A single-compartment electrochemical cell contained a pre-polished platinum disk working electrode $(d=0.5 \mathrm{~mm})$, a platinum wire counter electrode, and a silver wire pseudo-reference electrode. Dry $\mathrm{CH}_{2} \mathrm{Cl}_{2}$, deaerated by bubbling with argon for $10 \mathrm{~min}$, was used to prepare solutions of $10^{-3} \mathrm{M}$ complexes and $10^{-1} \mathrm{M} n-\mathrm{Bu}_{4} \mathrm{NPF}_{6}$ (dry, recrystallized) added as the supporting electrolyte. Ferrocene served as an internal reference for $E_{1 / 2}$ values and rapid electron transfer at the anode reflected in identical $\Delta E_{\mathrm{p}}$ values for each reversible redox couple. Chemical oxidation of parent complexes to corresponding mono- and dications was carried out by adding equivalent amounts of ferrocenium hexafluorophosphate. ${ }^{[11 \mathrm{a}]}$ EPR spectra was recorded on a Bruker BioSpin spectrometer, using a microwave frequency of about $9.84 \mathrm{GHz}, 100 \mathrm{kHz}$ modulation frequency, $1 \mathrm{G}$ modulation amplitude, and ca $20 \mathrm{~mW}$ power of the microwave. 
Computational Details. Density functional theory (DFT) calculations were performed using the Gaussian 09 software ${ }^{[49]}$ at the B3LYP/6-31G* (Lanl2dz for the $\mathrm{Ru}$ atom) and BLYP35 $5^{[38]} / 6-31 \mathrm{G}^{*}$ (Lanl2dz for the $\mathrm{Ru}$ atom) levels of theory. Geometry optimizations and full geometry optimizations were performed without any symmetry constraints, and frequency calculations on the resulting optimized geometries showed no imaginary frequencies. Electronic transitions were calculated by the time-dependent DFT (TD-DFT) method. The MO contributions were generated using GaussView 5.0. The solvation effects in dichloromethane were included for a part of the calculations with the conductor-like polarizable continuum model $(\mathrm{CPCM})^{[50]}$. Calculated harmonic vibrational frequencies were scaled by an empirical factor of 0.95 (BLYP35) and 0.9614 (B3LYP). ${ }^{[51,52]}$

\title{
Acknowledgements
}

The authors acknowledge the financial support from National Natural Science Foundation of China (21272088, 21472059, 21402057, 21602049), the Natural Science Foundation of Hunan Province, China (Nos. 2017JJ3004), F.H. also thanks the University of Reading for the continued support of the Spectroelectrochemistry Reading laboratories (project D14-015) and the CCNU Wuhan for his participation in the Global Talent Plan 111 project.

\author{
Author Information \\ Corresponding Authors \\ *E-mail: chshliu@mail.ccnu.edu.cn (S.H.L.); f.hartl@reading.ac.uk (F.H.). \\ ORCID
}

Frantisek Hartl: 0000-0002-7013-5360

\section{Notes}

The authors declare no competing financial interest.

$\dagger$ Electronic supplementary information (ESI) available: IR and UV-vis-NIR spectra, calculated DFT data, and NMR information. CCDC number 1504782 \& 
1504783 for 7 and 8. ESI and crystallographic data in CIF or other electronic format are available free of charge via the Internet at http://pubs.acs.org.

\section{References}

[1] (a) Yao, L. Y.; Hau, F. K.-W.; Yam, V. W.-W. Addition reaction-induced cluster-to-cluster transformation: controlled self-assembly of luminescent polynuclear gold(I) $\mu_{3}$-sulfido clusters. J. Am. Chem. Soc. 2014, 136, 10801-10806. (b) Bräunlich, I.; Sánchez-Ferrer, A.; Bauer, M.; Schepper, R.; Knüsel, P.; Dshemuchadse, J.; Mezzenga, R.; Caseri, W. Polynuclear iron (II)-aminotriazole spincrossover complexes (polymers) in solution. Inorg. Chem. 2014, 53, 3546-3557. (c) Nakano, M.; Oshio, H. Magnetic anisotropies in paramagnetic polynuclear metal complexes. Chem. Soc. Rev. 2011, 40, 3239-3248. (d) Coe, B. J. Developing iron and ruthenium complexes for potential nonlinear optical applications. Coord. Chem. Rev. 2013, 257, 1438-1458. (e) Fink, D.; Weibert, B.; Winter, R. F. Redox-active tetraruthenium metallacycles: reversible release of up to eight electrons resulting in strong electrochromism. Chem. Commun. 2016, 52, 6103-6106. (f) Zhong, Y. W.; Gong, Z. L.; Shao, J. Y.; Yao, J. Electronic coupling in cyclometalated ruthenium complexes. Coord. Chem. Rev. 2016, 312, 22-40. (g) Roué, S.; Sahnoune, H.; Toupet, L.; Halet, J. F.; Lapinte, C. Double insertion of thiophene rings in polyynediyl chains to stabilize nanoscaled molecular wires with [FeCp*(dppe)] termini. Organometallics 2016, 35, 2057-2070. (h) Yu, W. Y.; Meng, M.; Lei, H.; He, X. D.; Liu, C. Y. Optical Determination of Electron Transfer Dynamics and Kinetics for Asymmetrical $\left[\mathrm{Mo}_{2}\right]-\mathrm{ph}-\left[\mathrm{Mo}_{2}\right]$ Systems. J. Phys. Chem. C 2016, 120, 12411-12422. (i) Reger, D. L.; Pascui, A. E.; Foley, E. A.; Smith, M. D.; Jezierska, J.; Wojciechowska, A.; Stoian, S. A.; Ozarowski, A. Dinuclear metallacycles with single $\mathrm{M}-\mathrm{X}-\mathrm{M}$ bridges $(\mathrm{X}=\mathrm{Cl}, \mathrm{Br}$; $\mathrm{M}=\mathrm{Fe}(\mathrm{II}), \mathrm{Co}(\mathrm{II}), \mathrm{Ni}(\mathrm{II})$, $\mathrm{Cu}(\mathrm{II}), \mathrm{Zn}(\mathrm{II}), \mathrm{Cd}(\mathrm{II}))$ : strong antiferromagnetic superexchange interactions. Inorg. Chem. 2017, 56, 2884-2901. 
[2] (a) Long, N. J. Organometallic compounds for nonlinear optics - the search for en-light-enment! Angew. Chem. Int. Ed. Engl. 1995, 34, 21-38. (b) Chan, C. K. M.; Tao, C.-H.; Tam, H.-L.; Zhu, N.; Yam, V. W.-W.; Cheah, K. W. Synthesis, characterization, luminescence, and non-linear optical properties of oxadiazole-and truxene-containing platinum (II) alkynyl complexes with donoracceptor functionalities. Inorg. Chem. 2009, 48, 2855-2864.

[3] (a) Aguirre-Etcheverry, P.; O’Hare, D. Electronic communication through unsaturated hydrocarbon bridges in homobimetallic organometallic complexes. Chem. Rev. 2010, 110, 4839-4864. (b) Ceccon, A.; Santi, S.; Orian, L.; Bisello, A. Electronic communication in heterobinuclear organometallic complexes through unsaturated hydrocarbon bridges. Coord. Chem. Rev. 2004, 248, 683-724. (c) Low, P. J. Twists and turns: studies of the complexes and properties of bimetallic complexes featuring phenylene ethynylene and related bridging ligands. Coord. Chem. Rev. 2013, 257, 1507-1532. (d) Sakamoto, R.; Katagiri, S.; Maeda, H.; Nishihara, H. Bis(terpyridine) metal complex wires: excellent long-range electron transfer ability and controllable intrawire redox conduction on silicon electrode. Coord. Chem. Rev. 2013, 257, 1493-1506. (e) Kaim, W.; Lahiri, G. K. Unconventional mixed-valent complexes of ruthenium and osmium. Angew. Chem. Int. Ed. 2007, 46, 1778-1796.

[4] (a) Halet, J.-F.; Lapinte, C. Charge delocalization vs localization in carbon-rich iron mixed-valence complexes: a subtle interplay between the carbon spacer and the (dppe)Cp*Fe organometallic electrophore. Coord. Chem. Rev. 2013, 257, 1584-1613. (b) Makhoul, R.; Sahnoune, H.; Dorcet, V.; Halet, J.-F.; Hamon, J.-R.; Lapinte, C. 1,2-diethynylbenzene-bridged $[\mathrm{Cp} *(\mathrm{dppe}) \mathrm{Fe}]^{\mathrm{n}+}$ units: effect of steric hindrance on the chemical and physical properties. Organometallics 2015, 34, 3314-3326.

[5] (a) Kaim, W.; Klein, A.; Glöckle, M. Exploration of mixed-valence chemistry: inventing new analogues of the Creutz-Taube ion. Acc. Chem. Res. 2000, 33, 755-763. (b) Kaim, W.; Sarkar, B. Mixed valency in ruthenium complexes-Coordinative aspects. Coord. Chem. Rev. 2007, 251, 584-594. (c) 
Kaim, W.; Fiedler, J. Spectroelectrochemistry: the best of two worlds. Chem. Soc. Rev. 2009, 38, 3373-3382.

[6] (a) Linseis, M.; Záliš, S.; Zabel, M.; Winter, R. F. Ruthenium stilbenyl and diruthenium distyrylethene complexes: aspects of electron delocalization and electrocatalyzed isomerization of the Z-isomer. J. Am. Chem. Soc. 2012, 134, 16671-16692. (b) Scheerer, S.; Rotthowe, N.; Abdel-Rahman, O. S.; He, X.; Rigaut, S.; Kvapilová, H.; Záliš, S. Winter, R. F. Vinyl ruthenium-modified biphenyl and 2,2'-bipyridines. Inorg. Chem. 2015, 54, 3387-3402.

[7] Bruce, M. I.; Burgun, A.; Fox, M. A.; Jevric, M.; Low, P. J.; Nicholson, B. K.; Parker, C. R.; Skelton, B. W.; White, A. H.; Zaitseva, N. N. Some ruthenium derivatives of penta-1,4-diyn-3-one. Organometallics 2013, 32, 3286-3299.

[8] (a) Hildebrandt, A.; Lang, H. (Multi)ferrocenyl five-membered heterocycles: excellent connecting units for electron transfer studies. Organometallics 2013, 32, 5640-5653. (b) Miesel, D.; Hildebrandt, A.; Korb, M.; Schaarschmidt, D.; Lang, H. Transition-metal carbonyl complexes of 2,5-diferrocenyl-1-phenyl-1H-phosphole. Organometallics 2015, 34, 4293-4303.

[9] Cao, Z.; Xi, B.; Jodoin, D. S.; Zhang, L.; Cummings, S. P.; Gao, Y.; Tyler, S. F.; Fanwick, P. E.; Crutchley, R. J.; Ren, T. Diruthenium-polyyn-diyl-diruthenium wires: electronic coupling in the long-distance regime. J. Am. Chem. Soc. 2014, $136,12174-12183$.

[10] (a) Yao, C.-J.; Zhong, Y.-W.; Yao, J. Charge delocalization in a cyclometalated bisruthenium complex bridged by a noninnocent 1,2,4,5-tetra(2-pyridyl)benzene ligand. J. Am. Chem. Soc. 2011, 133, 15697-15706. (b) Yang, W-W.; Shao, J.-Y.; Zhong, Y-W. Cyclometalated diruthenium complexes bridged by 3,3',5,5'-tetra (pyrid-2-yl)biphenyl: tuning of electronic properties and intervalence charge transfer by terminal ligand effects. Eur. J. Inorg. Chem. 2015, 3195-3204.

[11] (a) Ou, Y.-P.; Xia, J.; Zhang, J.; Xu, M.; Yin, J.; Yu, G.-A.; Liu, S. H. Experimental and theoretical studies of charge delocalization in biruthenium-alkynyl complexes bridged by thiophenes. Chem. Asian J. 2013, 8, 2023-2032. (b) Zhang, J.; Sun, C.-F.; Zhang, M.-X.; Hartl, F.; Yin, J.; Yu, G-A.; 
Rao, L.; Liu, S. H. Asymmetric oxidation of vinyl-and ethynyl terthiophene ligands in triruthenium complexes. Dalton Trans. 2016, 45, 768-782. (c) Zhang, J.; Guo, S. Z.; Dong, Y. B.; Rao, L.; Yin, J.; Yu, G. A.; Hartl, F.; Liu, S. H. Multistep oxidation of diethynyl oligophenylamine-bridged diruthenium and diiron complexes. Inorg. Chem. 2017, 56, 1001-1015. (d) Khoo, K. H.; Chen, Y.; Li, S.; Quek, S. Y. Length dependence of electron transport through molecular wires-a first principles perspective. Phys. Chem. Chem. Phys. 2015, 17, 77-96.

[12] (a) Gong, Z.-L.; Yao, C.-J.; Shao, J.-Y.; Nie, H.-J.; Tang, J.-H.; Zhong, Y.-W. Redox-responsive carbometalated ruthenium and osmium complexes. Sci. China Chem. 2017, 60, 583-590. (b) Tang, J. H.; Shao, J. Y.; He, Y. Q.; Wu, S. H.; Yao, J.; Zhong, Y. W. Transition from a metal-localized mixed-valence compound to a fully delocalized and bridge-biased electrophore in a ruthenium-amine-ruthenium tricenter system. Chem. -Eur. J. 2016, 22, 10341-10345.

[13] (a) Zhang, J.; Zhang, M.-X.; Sun, C.-F.; Xu, M.; Hartl, F.; Yin, J.; Yu, G.-A.; Rao, L.; Liu, S. H. Diruthenium complexes with bridging diethynyl polyaromatic ligands: synthesis, spectroelectrochemistry, and theoretical calculations. Organometallics 2015, 34, 3967-3978. (b) Fox, M. A.; Guennic, B. L.; Roberts, R. L.; Brue, D. A.; Yufit, D. S.; Howard, J. A. K.; Manca, G.; Halet, J.-F.; Hartl, F.; Low, P. J. Simultaneous bridge-localized and mixed-valence character in diruthenium radical cations featuring diethynylaromatic bridging ligands. J. Am. Chem. Soc. 2011, 133, 18433-18446.

[14] D'Aléo, A.; Welter, S.; Cecchetto, E.; De Cola, L. Electronic energy transfer in dinuclear metal complexes containing meta-substituted phenylene units. Pure Appl. Chem. 2005, 77, 1035-1050.

[15] Tsivgoulis, G. M.; Lehn, J.-M. Photonic molecular devices: reversibly photoswitchable fluorophores for nondestructive readout for optical memory. Angew. Chem. Int. Ed. Engl. 1995, 34, 1119-1122.

[16] Kwon, T.-H.; Armel, V.; Nattestad, A.; MacFarlane, D. R.; Bach, U.; Lind, S. J.; Gordon, C.; Tang, W.; Jones, D. J.; Holmes, A. B. Dithienothiophene 
(DTT)-based dyes for dye-sensitized solar cells: synthesis of 2,6-dibromo-DTT. J. Org. Chem. 2011, 76, 4088-4093.

[17] Chen, M. C.; Chiang, Y. J.; Kim, C.; Guo, Y. J.; Chen, S. Y.; Liang, Y. J.; Huang, Y. W.; Hu, T.-S.; Lee, G-H.; Facchetti, A.; Marks, T. J. One-pot $[1+1+1]$

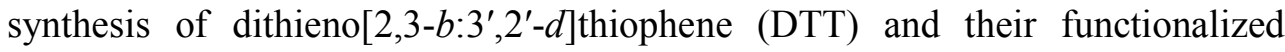
derivatives for organic thin-film transistors. Chem. Commun. 2009, 1846-1848.

[18] Li, P.; Ahrens, B.; Feeder, N.; Raithby, P. R.; Teat, S. J.; Khan, M. S. Luminescent digold ethynyl thienothiophene and dithienothiophene complexes; their synthesis and structural characterisation. Dalton. Trans. 2005, 874-883.

[19] Roué, S.; Stang, S. L.; Toupet, L.; Lapinte. C. Magnetic communication between two $\left[\left(\eta^{5}-\mathrm{C}_{5} \mathrm{Me}_{5}\right)\left(\eta^{2}\right.\right.$-dppe $\left.) \mathrm{Fe}(\mathrm{III})\right]$ units mediated by the 2,5-bis(ethynyl)thiophene spacer. C. R. Chimie 2003, 6, 353-366.

[20] Gao, L.-B.; Kan, J.; Fan, Y.; Zhang, L.-Y.; Liu, S. H.; Chen, Z.-N. Wirelike dinuclear ruthenium complexes connected by bis(ethynyl)oligothiophene. Inorg. Chem. 2007, 46, 5651-5664.

[21] (a) Dembinski, R.; Bartik, T.; Bartik, B.; Jaeger, M.; Gladysz, J. A. Toward Metal-capped one-dimensional carbon allotropes: Wirelike $\mathrm{C}_{6}-\mathrm{C}_{20}$ polyynediyl chains that span two redox-active $\left(\eta^{5}-\mathrm{C}_{5} \mathrm{Me}_{5}\right) \mathrm{Re}(\mathrm{NO})\left(\mathrm{PPh}_{3}\right)$ endgroups. $J . A m$. Chem. Soc. 2000, 122, 810-822. (b) Baranová, Z.; Amini, H.; Bhuvanesh, N.; Gladysz, J. A. Rotaxanes derived from dimetallic polyynediyl complexes: extended axles and expanded macrocycles. Organometallics 2014, 33, 6746-6749.

[22] (a) Mishra, A.; Ma, C.-Q.; Bauerle, P. Functional oligothiophenes: molecular design for multidimensional nanoarchitectures and their applications. Chem. Rev. 2009, 109, 1141-1276. (b) Niimi, K.; Shinamura, S.; Osaka, I.; Miyazaki, E.; Takimiya, K. Dianthra[2,3-b:2',3'-f]thieno[3,2-b]thiophene (DATT): synthesis, characterization, and FET characteristics of new $\pi$-extended heteroarene with eight fused aromatic rings. J. Am. Chem. Soc. 2011, 133, 8732-8739. (c) Kumar, R.; Pillai, R. G.; Pekas, N.; Wu, Y.; McCreery, R. L. Spatially resolved Raman spectroelectrochemistry of solid-state polythiophene/viologen memory devices. $J$. 
Am. Chem. Soc. 2012, 134, 14869-14876.

[23] Fuller, L. S.; Iddon, B.; Smith, K. A. Thienothiophenes. Part 2. 1 Synthesis, metallation and bromine $\rightarrow$ lithium exchange reactions of thieno[3,2-b]thiophene and its polybromo derivatives. J. Chem. Soc., Perkin Trans. 11997. $3465-3470$.

[24] (a) Coombs, B. A.; Beeby, C. 2,5-bis(Arylethynyl) thienyl systems: preparation and photophysical properties. Part II. RSC Advances 2012, 2, 1870-1876. (b) Gather, M. C.; Campbell, Alasdair J. An alignable fluorene thienothiophene copolymer with deep-blue electroluminescent emission at $410 \mathrm{~nm}$. Chem. Commun. 2008, 1079-1081.

[25] Youn, J.; Huang, P.-Y.; Huang, Y-W.; Chen, M.-C.; Lin, Y.-J.; Huang, H.; Ortiz, R. P.; Stern, C.; Chung, M.-C.; Feng, C.-Y.; Chen, L.-H.; Facchetti, A.; Marks, T. J. Versatile $\alpha, \omega$-disubstituted tetrathienoacene semiconductors for high performance organic thin-film transistors. Adv. Funct. Mater. 2012, 22, 48-60.

[26] Wu, X.-H.; Liang, J. H.; Xia, J.-L.; Jin, S.; Yu, G.-A.; Liu, S. H. Bimetallic ruthenium complexes: synthesis, characterization, and the effect of appending long carbon chains to their bridges. Organometallics 2010, 29, 1150-1156.

[27] (a) Fox, M. A.; Farmer, J. D.; Roberts, R. L.; Humphrey, M. G.; Low, P. J. Non-innocent ligand behavior in diruthenium complexes containing a 1 , 3-diethynylbenzene bridge. Organometallics 2009, 28, 5266-5269. (b) Armitt, D. J.; Bruce, M. I.; Gaudio, M.; Zaitseva, N. N.; Skelton, B. W.; White, A. H.; Guennic, B. L.; Halet, J.-F.; Fox, M. A.; Roberts, R. L.; Hartl, F.; Low, P. J. Some transition metal complexes derived from mono- and di-ethynyl perfluorobenzenes. Dalton Trans. 2008, 6763-6775.

[28] Okamoto, T.; Kudoh, K.; Wakamiya, A.; Yamaguchi, S. General synthesis of extended fused oligothiophenes consisting of an even number of thiophene rings. Chem. -Eur. J. 2007, 13, 548-556.

[29] D'Alessandro, D. M.; Keene, F. R. A cautionary warning on the use of electrochemical measurements to calculate comproportionation constants for 
mixed-valence compounds. Dalton Trans. 2004, 3950-3954.

[30] Geiger, W. E.; Barriere, F. Organometallic electrochemistry based on electrolytes containing weakly-coordinating fluoroarylborate anions. Acc. Chem. Res. 2010, 43, 1030-1039.

[31] Lapinte, C. Magnetic perturbation of the redox potentials of localized and delocalized mixed-valence complexes. J. Organomet. Chem. 2008, 693, 793-801.

[32] (a) Paul, F.; Lapinte, C. Organometallic molecular wires and other nanoscale-sized devices: an approach using the organoiron (dppe)Cp*Fe building block. Coord. Chem. Rev. 1998, 178, 431-509. (b) Kim, B.; Beebe, J. M.; Olivier, C.; Rigaut, S.; Touchard, D.; Kushmerick, J. G.; Zhu, X. Y.; Frisbie, C. D. Temperature and length dependence of charge transport in redox-active molecular wires incorporating ruthenium (II) bis( $\sigma$-arylacetylide) complexes. $J$. Phys. Chem. C. 2007, 111, 7521-7526. (c) Kowalski, K.; Linseis, M.; Winter, R. F.; Zabel, M.; Zálišs, S.; Kelm, H.; Kruger, H. J.; Sarkar, B.; Kaim, W. Charge delocalization in a heterobimetallic ferrocene-(vinyl) $\mathrm{Ru}(\mathrm{CO}) \mathrm{Cl}\left(\mathrm{P}^{i} \operatorname{Pr}_{3}\right)_{2}$ system dedicated to Prof. Dr. Helmut Werner on the occasion of his 75 th birthday. Organometallics 2009, 28, 4196-4209.

[33] (a) Aragó, J.; Viruela, P. M.; Ortí, E.; Osuna, R. M.; Vercelli, B.; Zotti, G.; Hernández, V.; Navarrete, J. T. L.; Henssler, J. T.; Matzger, A. J.; Suzuki, Y.; Yamaguchi, S. Neutral and oxidized triisopropylsilyl end-capped oligothienoacenes: a combined electrochemical, spectroscopic, and theoretical study. Chem. -Eur. J. 2010, 16, 5481-5491. (b) Rizalman, N. S.; Capel Ferrón, C.; Niu, W.; Wallace, A. L.; He, M.; Balster, R; Lampkin, J.; Hernández, V.; Navarrete, J. T. L.; Ruiz Delgado, M. C.; Hartl, F. Radical cations of end-capped tetrathienoacenes and their $\pi$-dimerization controlled by the nature of $\alpha$-substituents and counterion concentration. RSC Adv. 2013, 3, 25644-25647.

(c) Capel Ferrón, C.; Capdevila-Cortada, M.; Balster, R.; Hartl, F.; Niu, W.; He, M’; Novoa, J. J.; López Navarrete, J. T.; Hernández, V.; Ruiz Delgado, M. C. 
Multistep $\pi$-Dimerisation of Heptathienoacene Radical Cations: A Spectro-Electrochemical and DFT Study. Chem. Eur. J. 2014, 20, 10351-10359.

[34] Richardson, D. E.; Taube, H. Determination of $E_{2}^{\circ}-E_{1}{ }^{\circ}$ in multistep charge transfer by stationary-electrode pulse and cyclic voltammetry: application to binuclear ruthenium ammines. Inorg. Chem. 1981, 20, 1278-1285.

[35] Ou, Y. P.; Zhang, J.; Zhang, F.; Kuang, D.; Hartl, F.; Rao, L.; Liu, S. H. Notable differences between oxidized diruthenium complexes bridged by four isomeric diethynyl benzodithiophene ligands. Dalton Trans. 2016, 45, 6503-6516.

[36] Pfaff, U.; Hildebrandt, A.; Korb, M.; Schaarschmidt, D.; Rosenkranz, M.; Popov, A.; Lang, H. Five-membered heterocycles as linking units in strongly coupled homobimetallic group 8 metal half-sandwich complexes. Organometallics 2015, $34,2826-2840$.

[37] (a) Parthey, M.; Gluyasz, J. B. G.; Schauer, P. A.; Yufit, D. S.; Howard, J. A. K.; Kaupp, M.; Low, P. J. Refining the interpretation of near-infrared band shapes in a polyynediyl molecular wire. Chem. -Eur. J. 2013, 19, 9780-9784. (b) Marqués-González, S.; Parthey, M.; Yufit, D. S.; Howard, J. A. K.; Kaupp, M.; Low, P. J. Combined spectroscopic and quantum chemical study of [trans-Ru $\left.\left(\mathrm{C} \equiv \mathrm{CC}_{6} \mathrm{H}_{4} \mathrm{R}_{1-4}\right)_{2}(\text { dppe })_{2}\right]^{\mathrm{n}+} \quad$ and $\quad\left[\right.$ trans $-\mathrm{Ru}\left(\mathrm{C} \equiv \mathrm{CC}_{6} \mathrm{H}_{4} \mathrm{R}_{1}-4\right)\left(\mathrm{C} \equiv \mathrm{CC}_{6} \mathrm{H}_{4} \mathrm{R}_{2}-4\right)$ $\left.(\text { dppe })_{2}\right]^{\mathrm{n}+}(\mathrm{n}=0,1)$ complexes: interpretations beyond the lowest energy conformer paradigm. Organometallics 2014, 33, 4947-4963.

[38] (a) Parthey, M.; Kaupp, M. Quantum-chemical insights into mixed-valence systems: within and beyond the Robin-Day scheme. Chem. Soc. Rev. 2014, 43, 5067-5088. (b) Renz, M.; Theilacker, K.; Lambert, C.; Kaupp, M. A reliable quantum-chemical protocol for the characterization of organic mixed-valence compounds. J. Am. Chem. Soc. 2009, 131, 16292-16302. (c) Kaupp, M.; Renz, M.; Parthey, M.; Stolte, M.; Würthner, F.; Lambert, C. Computational and spectroscopic studies of organic mixed-valence compounds: where is the charge? Phys. Chem. Chem. Phys. 2011, 13, 16973-16986.

[39]Linseis, M.; Záliš, S.; Zabel, M.; Winter, R. F. Ruthenium stilbenyl and diruthenium distyrylethene complexes: aspects of electron delocalization and 
electrocatalyzed isomerization of the $Z$-isomer. J. Am. Chem. Soc. 2012, 134, $16671-16692$.

[40]Winter, R. F.; Hornung, F. M. Trapping of a ruthenium-butatrienylidene intermediate by tertiary amines. 2-ammoniobutenynyl complexes. Organometallic 1999, 18, 4005-4014.

[41] Patra, S.; Sarkar, B.; Ghumaan, S.; Fiedler, J.; Záliš, S.; Kaim, W.; Lahiri, G. K. $\left\{(\mu-\mathrm{L})\left[\mathrm{Ru}^{\mathrm{II}}(\mathrm{acac})_{2}\right]_{2}\right\}^{n}, \quad n=2+, \quad+, \quad 0, \quad-, \quad 2-, \quad$ with $\quad \mathrm{L}=3,3^{\prime}, 4,4^{\prime}-$ tetraimino-3,3',4,4'-tetrahydrobiphenyl. EPR-supported assignment of NIR absorptions for the paramagnetic intermediates. Dalton. Trans. 2004, 750-753.

[42] Bellinger-Buckley, S.; Chang, T. C.; Bag, S.; Schweinfurth, D.; Zhou, W.; Torok, B.; Sarkar, B.; Tsai, M.-K.; Rochford, J. Exploring the noninnocent character of electron rich $\pi$-extended 8-oxyquinolate ligands in ruthenium (II) bipyridyl complexes. Inorg. Chem. 2014, 53, 5556-5567.

[43] Paul, F.; Ellis, B. G.; Bruce, M. I.; Toupet, L.; Roisnel, T.; Costuas K.; Halet, J.-F.; Lapinte, C. Bonding and substituent effects in electron-rich mononuclear ruthenium $\sigma$-arylacetylides of the formula $\left[\left(\eta^{2}\right.\right.$-dppe $\left.)\left(\eta^{5}-\mathrm{C}_{5} \mathrm{Me}_{5}\right) \mathrm{Ru}(\mathrm{C} \equiv \mathrm{C})-1,4-\left(\mathrm{C}_{6} \mathrm{H}_{4}\right) \mathrm{X}\right]\left[\mathrm{PF}_{6}\right]_{n}\left(n=0,1 ; \mathrm{X}=\mathrm{NO}_{2}, \mathrm{CN}, \mathrm{F}, \mathrm{H}\right.$, OMe, $\mathrm{NH}_{2}$ ). Organometallics 2006, 25, 649-665.

[44] Bruce, M. I.; Ellis, B. G.; Low, P. J.; Skelton, B. W.; White, A. H. Syntheses, structures, and spectro-electrochemistry of $\{\mathrm{Cp} *(\mathrm{PP}) \mathrm{Ru}\} \mathrm{C} \equiv \mathrm{CC} \equiv \mathrm{C}\{\mathrm{Ru}(\mathrm{PP})$ $\left.\mathrm{Cp}^{*}\right\}(\mathrm{PP}=\mathrm{dppm}, \mathrm{dppe})$ and their mono-and dications. Organometallics 2003, 22, 3184-3198.

[45] Seidler, A.; Svoboda, J.; Dekoj, V.; Chocholoušová, J. V.; Vacek, J.; Stará, I. G.; Starý, I. The synthesis of $\pi$-electron molecular rods with a thiophene or thieno[3,2-b]thiophene core unit and sulfur alligator clips. Tetrahedron Lett. 2013, 54, 2795-2798.

[46] Miguel, L. S.; Porter, W. W.; Matzge, A. J.; Planar $\beta$-linked oligothiophenes

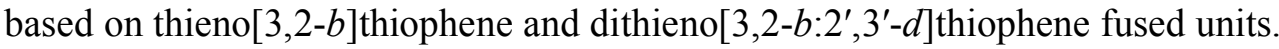
Org. Lett. 2007, 9, 1005-1008.

[47] Sheldrick, G. M. SHELXS-97, a Program for Crystal Structure Solution; 
University of Göttingen: Göttingen, Germany, 1997.

[48] Sheldrick, G. M. SHELXL-97, a Program for Crystal Structure Refinement; University of Göttingen, Göttingen, Germany, 1997.

[49] Gaussian 09, Revision D.01, Frisch, M. J.; Trucks, G. W.; Schlegel, H. B.; Scuseria, G. E.; Robb, M. A.; Cheeseman, J. R.; Scalmani, G.; Barone, V.; Mennucci, B.; Petersson, G. A.; Nakatsuji, H.; Caricato, M.; Li, X.; Hratchian, H. P.; Izmaylov, A. F.; Bloino, J.; Zheng, G.; Sonnenberg, J. L.; Hada, M.; Ehara, M.; Toyota, K.; Fukuda, R.; Hasegawa, J.; Ishida, M.; Nakajima, T.; Honda, Y.; Kitao, O.; Nakai, H.; Vreven, T.; Montgomery, J. A., Jr.; Peralta, J. E.; Ogliaro, F.; Bearpark, M.; Heyd, J. J.; Brothers, E.; Kudin, K. N.; Staroverov, V. N.; Kobayashi, R.; Normand, J.; Raghavachari, K.; Rendell, A.; Burant, J. C.; Iyengar, S. S.; Tomasi, J.; Cossi, M.; Rega, N.; Millam, J. M.; Klene, M.; Knox, J. E.; Cross, J. B.; Bakken, V.; Adamo, C.; Jaramillo, J.; Gomperts, R.; Stratmann, R. E.; Yazyev, O.; Austin, A. J.; Cammi, R.; Pomelli, C.; Ochterski, J. W.; Martin, R. L.; Morokuma, K.; Zakrzewski, V. G.; Voth, G. A.; Salvador, P.; Dannenberg, J. J.; Dapprich, S.; Daniels, A. D.; Farkas, Ö.; Foresman, J. B.; Ortiz, J. V.; Cioslowski, J.; Fox, D. J. Gaussian, Inc., Wallingford CT, 2009.

[50] Cossi, M.; Rega, N.; Scalmani, G.; Barone, V. Energies, structures, and electronic properties of molecules in solution with the C-PCM solvation model. $J$. Comput. Chem. 2003, 24, 669-681.

[51] Scott, A. P.; Radom, L. J. Phys. Chem. 1996, 100, 16502-16513.

[52] Röder, J. C.; Meyer, F.; Hyla-Kryspin, I.; Winter, R. F.; Kaifer, E. Chem. Eur. J. 2003, 9, 2636-2648. 


\section{TOC and Graphical Abstract}

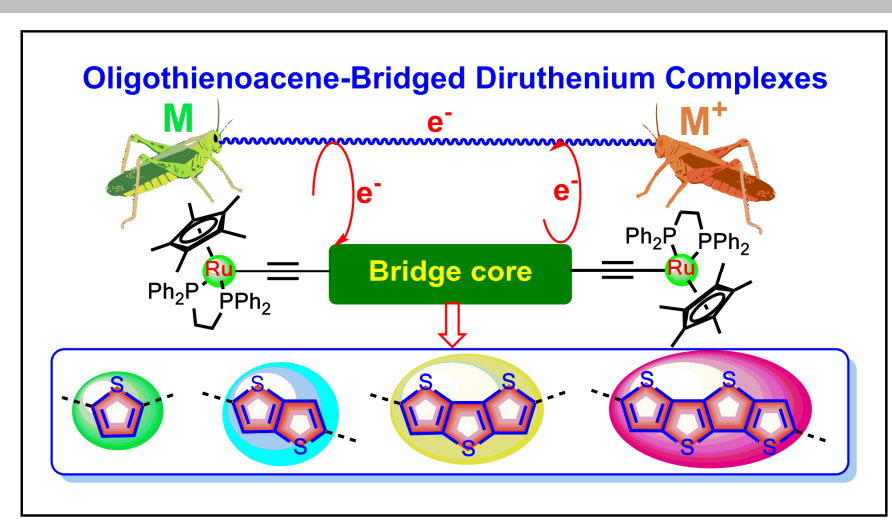

The localization of the HOMO of the parent diruthenium complexes on the redox non-innocent oligothienoacene bridge core with strong participation of the ethynyl linkers and a limited contribution from the metallic termini makes the initial one-electron oxidation symmetrical. The remarkable appearance of a dual $\mathrm{IR} v(\mathrm{C} \equiv \mathrm{C})$ absorption in the cationic complexes is ascribed to a vibronic coupling of the IR-forbidden $v_{\mathrm{s}}(\mathrm{C} \equiv \mathrm{C})$ mode of the oxidized $-[\mathrm{C} \equiv \mathrm{C}-\text { core }-\mathrm{C} \equiv \mathrm{C}]^{+}-$bridge to the low-lying $\pi-\pi^{*}$ (intra-bridge) / MLCT electronic transition in the NIR-mid-IR spectral region.
Ya-Ping Ou, Jing Zhang, Ming-Xing

Zhang, Fuxing Zhang, Daizhi Kuang,

František Hartl, * Sheng Hua Liu*

Page No. - Page No.

Title: Bonding and electronic properties of linear diethynyl oligothienoacene-bridged diruthenium complexes and their oxidized forms 